Author details:

Full name:

Dr Paul Gragl

Affiliation/Address:

Senior Lecturer in Law at Queen Mary, University of London

Department of Law; Mile End Road; London E1 4NS

Telephone/Email:

+44(0)207882 3956 / p.gragl@qmul.ac.uk

\title{
ARTICLE
}

\section{In Defence of Kelsenian Monism: Countering Hart and Raz}

\section{Paul Gragl*}

This paper discusses the main criticism launched against legal monism and the Pure Theory of Law, as envisaged by Hans Kelsen and the other proponents of the Vienna School of Jurisprudence, namely the criticism voiced by two of the most eminent legal theorists, H.L.A. Hart and Joseph Raz. According to them, legal monism fails to offer a satisfactory theory of the identity of legal systems and it therefore simply cannot be considered a viable theory of legal systems, because it leads to obviously absurd consequences. These arguments which take the form of an attack on the most basic tenets of the Pure Theory of Law and thus legal monism, will be duly addressed and consequently rebutted in this paper, particularly in order to be able to maintain legal monism in its juridicoepistemological manifestation as a working and viable theory of the law.

Keywords: monism; basic norm; hierarchy of norms; unity of the law; identity of legal orders; Hans Kelsen; Adolf Julius Merkl; Alfred Verdross; Josef L. Kunz; Pure Theory of Law; Immanuel Kant; transcendental philosophy; H.L.A. Hart; Joseph Raz.

\footnotetext{
* Senior Lecturer in Law at the Department of Law; Queen Mary, University of London. The author would like to thank Professor Alexander Somek, University of Vienna, and the two anonymous reviewers for their helpful and insightful comments. All errors and omissions of course remain the author's.
} 


\section{INTRODUCTION}

It may not be chic to confess to being a legal monist these days, in particular because of the apparently dualist state of the international legal order which lacks effective enforcement mechanisms ${ }^{1}$ and hence requires transposition to penetrate the national legal order in order to take full effect within it. ${ }^{2}$ Furthermore legal pluralism, in contrast to monism, displays immensely appealing features such as 'good, progressive, tolerant, non-domineering' - in contrast to the characteristics of hierarchically ordered systems: 'bad, regressive, intolerant, domineering. ${ }^{3}$ Besides the direct and intuitive appeal of both dualism and pluralism, the main reason why legal monism (as envisaged by Hans Kelsen and other proponents of the Pure Theory of $\mathrm{Law}^{4}$ ) is unfashionable among legal theorists and scholars these days is that according to prevailing opinion - it has decisively been refuted by two of the most eminent legal theorists, namely H.L.A Hart in his essay 'Kelsen's Doctrine of the Unity of Law' 5 and Joseph Raz, in particular in his book The Concept of a Legal System. ${ }^{6}$ In general, Hart and Raz also argue that laws exist as part of legal systems ${ }^{7}$ or that there is a system-constituting social rule, i.e. the rule of recognition, which specifies the membership conditions of legal norms. ${ }^{8}$ Yet neither of them ever went as far as Kelsen and declared that all legal norms in the world necessarily formed part of a unitary legal order. ${ }^{9}$ According to their criticism, legal monism fails to offer a satisfactory theory of the identity of legal systems and therefore it simply cannot be considered a viable theory of a legal system, because it leads to obviously absurd

\footnotetext{
${ }^{1}$ Stefan Griller, 'Völkerrecht und Landesrecht - unter Berücksichtigung des Europarechts' in Robert Walter, Clemens Jabloner, and Klaus Zeleny (eds), Hans Kelsen und das Völkerrecht (Vienna: Manz, 2004) 90-93.

${ }^{2}$ Tom Ginsburg, Svitlana Chernykh, and Zachary Elkins, 'Commitment and Diffusion: How and Why National Constitutions Incorporate International Law' (2008) 2008 University of Illinois Law Review 201, 204.

${ }^{3}$ J.H.H. Weiler, 'Prologue: Global and Pluralist Constitutionalism - Some Doubts' in Gráinne de Búrca and J.H.H. Weiler (eds), The Worlds of European Constitutionalism (Cambridge: Cambridge University Press, 2012) 14.

${ }^{4}$ At this point, it should be emphasized that this paper is not about Hans Kelsen alone. Most of the academic literature in Anglo-American legal theory seems to be focusing exclusively on him, which does not do justice to the other thinkers and writers of the Vienna School of Jurisprudence. Kelsen may have been the most prominent and well-known proponent of this particular school of legal thinking, but the most notable influences on his work - particularly by Adolf Julius Merkl, Alfred Verdross, and Josef L. Kunz - should not be neglected.

${ }^{5}$ Hart's essay was first published in Howard E. Kiefer and Milton K. Munitz (eds), Ethics and Social Justice (Albany: State University of New York Press, 1968). For references to his essay in this paper, cf. the reprinted version: H.L.A Hart, 'Kelsen's Doctrine of the Unity of Law' in Stanley L. Paulson and Bonnie Litschewski Paulson (eds), Normativity and Norms: Critical Perspectives on Kelsenian Themes (reprint; Oxford: Clarendon Press, 2007) 553-581.

${ }^{6}$ Joseph Raz, The Concept of a Legal System: An Introduction to the Theory of Legal System $\left(2^{\text {nd }}\right.$ edn; Oxford: Oxford University Press, 1980). The first edition was published in 1970.

${ }^{7}$ Joseph Raz, 'The Identity of Legal Systems' (1971) 59 California Law Review 795-815.

${ }^{8}$ H.L.A. Hart, The Concept of Law (2 ${ }^{\text {nd }}$ edn; Oxford: Clarendon Press, 1994) 92.

${ }^{9}$ Michael Giudice, 'Hart and Kelsen on International Law' in Leslie Green and Brian Leiter (eds), Oxford Studies in Philosophy of Law: Vol. 2 (Oxford: Oxford University Press, 2013) 148.
} 
consequences. The membership of norms in a given legal system can only be ascertained with reference to the social practices of identification, which characterize the activity of the primary law-applying institutions of that legal system. ${ }^{10}$

Given the impact of this criticism on the substantial value of the Pure Theory of Law as a theory to conceive of the law in general and on legal monism in particular, a scrutinizing analysis of Hart and Raz's arguments is immensely worthwhile. These arguments, which, in principle, take the form of an attack on the most basic tenets of the Pure Theory of Law and legal monism, must be duly addressed and credibly rebutted in order to maintain monism in the juridico-epistemological sense as a working and viable theory of the law. This paper undertakes this task, firstly, with regard to the arguments voiced by H.L.A. Hart, and subsequently by tackling those of Joseph Raz. By doing so, it mostly builds upon the arguments made by Lars Vinx in two of his contributions, ${ }^{11}$ but goes beyond them in various ways. ${ }^{12}$ Having said that, this paper should not be read as a type of 'Wittgenstein's poker', ${ }^{13}$ i.e. as giving an answer to the question of who has won this controversy between intellectual giants. It should first and foremost be seen as a defence of Kelsen, Verdross, and Kunz, and their concept of legal monism against misinterpretation. But it is also true that this approach in itself is not sufficient. Most importantly, even though the mere negative rebuttal of both Hart and Raz's criticism of monism and the Pure Theory of Law might be highly convincing in itself, this paper will also provide positive support for Kelsen's position. This will mostly be done by reference to the Kantian and neo-Kantian roots of the Pure Theory of Law through which it becomes evident - epistemologically as well as logically - that monism remains the only choice if we want to consider the law as having an objective meaning for everyone. ${ }^{14}$ It is of course well known that Kelsen took a radical turn away from Kantianism in his General Theory of

\footnotetext{
${ }^{10}$ Cf. Lars Vinx, Hans Kelsen's Pure Theory of Law: Legality and Legitimacy (Oxford: Oxford University Press, 2007) 182.

${ }^{11}$ Cf. in particular his analysis in Lars Vinx, 'The Kelsen-Hart Debate: Hart's Critique of Kelsen's Legal Monism Reconsidered' in Jeremy Telman (ed), Hans Kelsen in America - Selective Affinities and the Mysteries of Academic Influence (Dordrecht: Springer, 2016) X-Y, and Vinx, Hans Kelsen's Pure Theory of Law (n 10) 184194.

${ }^{12}$ Especially with regard to the epistemological roots of the Pure Theory of Law; the Grundnorm of international law and arguments in favour of a positive constitution of the international legal order (thus also going beyond the arguments of Jörg Kammerhofer); and the epistemological necessity of the primacy of international law (a view which is in contrast to Kelsen itself, but more in line with the views of his students Alfred Verdross and Josef L. Kunz).

${ }^{13}$ Cf. David Edmonds and John Eidinow, Wittgenstein's Poker: The Story of a Ten-Minute Argument Between Two Great Philosophers (reprint; New York: Harper Collins, 2001).

${ }^{14}$ Cf. Michael Green, 'Hans Kelsen and the Logic of Legal Systems' (2003) 54 Alabama Law Review 365, 381389.
} 
Norms (published posthumously in 1979) ${ }^{15}$ towards a rather anti-logical and more positivist approach. ${ }^{16}$ Yet nonetheless his intellectual development during his 'classical phase' (from circa 1921 to 1960) still represents the richest and most rewarding period in all of Kelsen's work in which he attempted to provide a Kantian or neo-Kantian mooring and transcendental undergirding for his legal theory. ${ }^{17}$

On the basis of this epistemological and logical groundwork, this paper intends to counter the overall claims by Hart and Raz that legal monism as presented by Kelsen is either trivially true and therefore not interesting, or interesting, but false. In fact, it will be argued that monism is both logically true and interesting, since it is able to provide any observer of the law with new information which goes beyond mere tautological truths. Through its central conceptions (such as the strict dichotomy of 'Is' and 'Ought', the basic norm, and the hierarchy of norms), the Pure Theory of Law succeeds in explaining the objective meaning of norms, ${ }^{18}$ which is 'legal validity', and in satisfactorily resolving conflicts between norms of different bodies of law. Only monism takes the concept of legal validity seriously, ${ }^{19}$ as will be explained in more detail below, and therefore it cannot be uninteresting to lawyers.

\section{H.L.A. HART AND KELSEN'S UNITY DOCTRINE}

According to Hart, it is Kelsen's most serious mistake to claim that all valid laws necessarily form a single system. The monist theory of national and international law, Hart continues, is simply unsuccessful because of the major fallacies Kelsen overlooked when envisaging this doctrine. ${ }^{20}$ Despite certain similarities between Hart and Kelsen and the latter's (albeit limited) influence on the former, Hart is rather anxious to clarify that his theory differs from the Pure

\footnotetext{
${ }^{15}$ Hans Kelsen, General Theory of Norms (reprint; Oxford: Clarendon Press, 2011). Cf. also Ota Weinberger, 'Logic and the Pure Theory of Norms' in Richard Tur and William Twining (eds), Essays on Kelsen (Oxford: Clarendon Press, 1986) 188.

${ }^{16}$ In the sense of 'contingent' or 'a posteriori' and thus in contrast to 'necessary' and 'a priori'.

${ }^{17}$ Stanley L. Paulson, 'Four Phases in Hans Kelsen's Legal Theory? Reflections on a Periodization' (1998) 18 Oxford Journal of Legal Studies 153, 155; Carsten Heidemann, Die Norm als Tatsache: Zur Normentheorie Hans Kelsens (Baden-Baden: Nomos, 1997) 43.

${ }^{18}$ Cf. Brian H. Bix, 'Rules and Normativity in Law' in Michał Araszkiewicz, Paweł Banaś, Tomasz GizbertStudnicki, and Krzysztof Płeszka (eds), Problems of Normativity, Rules, and Rules-Following (Heidelberg: Springer, 2015) 135.

${ }_{19}$ Alexander Somek, 'Monism: A Tale of the Undead' in Matej Avbelj and Jan Komárek (eds), Constitutional Pluralism in the European Union and Beyond (Oxford: Hart Publishing, 2012) 354-355.

${ }^{20}$ H.L.A. Hart, 'Answers to Eight Questions' in Luís Duarte D’Almeida, James Edwards, and Andrea Dolcetti (eds), Reading HLA Hart's The Concept of Law (Oxford: Hart Publishing, 2013) 290.
} 
Theory of Law in important ways. ${ }^{21}$ In this vein, Hart is a force to be reckoned with, and there is no way around his arguments. ${ }^{22}$ These very arguments will now be discussed in three separate steps: ${ }^{23}$ (1) the strong version of monism; (2) the problem of the basic norm; and (3) the principle of validating purport and the weak version of monism. ${ }^{24}$ All of these arguments will subsequently subjected to close scrutiny in order to save legal monism from theoretical obsolescence and absurdity.

\section{The Strong Version of Monism: Logical and Epistemological Necessity}

At the outset, Hart distinguishes between two versions of legal monism in Kelsen's writings. ${ }^{25}$ a strong version, according to which international and national law from one single legal order by logical and epistemological necessity; ${ }^{26}$ and a weaker version which states that although it is not necessarily true that all valid laws form one single legal order, it is, however, just the case as an empirical contingency that they do form such a single legal order. ${ }^{27}$ Yet the first problem in Hart's argument is that this distinction between these two different versions of monism cannot be sustained. Kelsen nowhere expounds a weak version of monism by exclusively pointing to the existence of the effectiveness principle as the positive legal provision that anchors the recognition of States in the existence of efficacious territorial legal orders of coercive rule. ${ }^{28}$

\footnotetext{
${ }^{21}$ Cf. in particular A.W. Brian Simpson, Reflections on The Concept of Law (Oxford: Oxford University Press, 2011) 114; Nicola Lacey, A Life of HLA Hart: The Nightmare and the Noble Dream (Oxford: Oxford University Press, 2004) 249-253.

${ }^{22}$ For an interesting debate on Hart and Kelsen's influence on legal philosophy during the twentieth century cf. e.g., Brian Leiter, 'The End of Empire: Dworkin and Jurisprudence in the $21^{\text {st }}$ Century' (2005) 36 Rutgers Law Journal 165, 168: Kelsen and Hart are the 'the two dominant figures in twentieth-century legal philosophy'; John Mikhail, "Plucking the Mask of Mystery from Its Face": Jurisprudence and H.L.A. Hart' (2007) 95 Georgetown Law Journal 733, 734: '[M] ost scholars would agree that Hart and Kelsen are the century's two greatest legal philosophers'; John Gardner, 'Publication Review: A Life of H.L.A. Hart: The Nightmare and the Noble Dream' (2005) 121 Law Quarterly Review 329, 333: '[O]nly Hans Kelsen seriously challenges Hart's claim to be the most important legal philosopher of the twentieth century'; Christoph Kletzer, 'The Role and Reception of the Work of Hans Kelsen in the United Kingdom' in Robert Walter, Clemens Jabloner, and Klaus Zeleny (eds), Hans Kelsen anderswo - Hans Kelsen abroad (Vienna: Manz, 2010) 144-157.

${ }^{23}$ Cf. Giudice (n 9) 157.

${ }^{24}$ As a fourth argument, one could add Hart's criticism that Kelsen cannot accept conflicts between valid laws in analogy to the logical principle of non-contradiction; cf. Hart, 'Kelsen's Doctrine of the Unity of Law' (n 5) 565574. Since the later Kelsen has, however, given up this claim and accepted the existence of normative conflicts (cf. especially Kelsen, General Theory of Norms (n 15) 106-114 and 123-127), this problem need not concern us at this point; cf. Hart, 'Answers to Eight Questions' (n 20) 290.

${ }^{25}$ Hart, 'Kelsen's Doctrine of the Unity of Law' (n 5) 554.

${ }^{26}$ Cf. Hans Kelsen, Pure Theory of Law ( $2^{\text {nd }}$ edn; Berkeley and Los Angeles: University of California Press, 1967) 329.

${ }^{27}$ Cf. Hans Kelsen, General Theory of Law and State (re-issue edn; New Brunswick/London: Transaction Publishers, 2007) 371-372; Kelsen, Pure Theory of Law (n 26) 330-331.

${ }^{28}$ Alexander Somek, 'Kelsen Lives' (2007) 18 European Journal of International Law 409, 426. Cf. also Hart,

'Kelsen's Doctrine of the Unity of Law' (n 5) 560-561.
} 
Let us nonetheless engage with Hart's objections against Kelsen's strong version of monism. Because of his artificial distinction into a weak and strong version of monism, Hart erroneously postulates that very little is to be found in support of the stronger thesis in Kelsen's works - even though Kelsen's entire work rests on this alleged strong version and his epistemological claims as derived from Kant and the neo-Kantians. Thus, quite the contrary is the case, and if there is any support for legal monism, it is to be found in these epistemological claims. For Kelsen, monism is an epistemological postulate of legal theory, as it is logically impossible to conceive of simultaneously valid norms belonging to different and mutually independent systems. ${ }^{29}$ The reason for this can be explained on the basis of the following line of argumentation which concurrently serves as a positive support for legal monism: Kelsen begins his Pure Theory of Law in both editions with the statement that, as a theory of positive law in general, its purpose is to know and to cognize its subject-matter, i.e. the law, in order to be able to describe it objectively and scientifically. ${ }^{30}$ Thus his theory needs to be understood as a universal epistemological tool which is capable of cognizing any positive legal order. ${ }^{31}$ To this end, Kelsen states that the source of his epistemological thoughts, elaborated in his theory, is based on Kant's transcendental philosophy and the philosophy of his neo-Kantian successors. ${ }^{32}$ In his Critique of Pure Reason, Immanuel Kant undertook to search for the principles of our experience that are both genuinely informative and universally and necessarily true - the so-called synthetic a priori ${ }^{33}$ which provides us with knowledge independent of empirical experience (a priori), but which nonetheless carries new information that goes beyond the mere clarification of what was already implicit in the given concepts (synthetic). ${ }^{34}$ In the same vein, Kelsen intends his theory to be capable of cognizing and identifying any given legal order a priori $^{35}$ as well as providing the observer with knowledge about said legal order. In other words, logically speaking, his theory is necessarily true, but it also provides the lawyer with information beyond mere trivial truths.

\footnotetext{
${ }^{29}$ Kelsen, General Theory of Law and State (n 27) 363 and 373.

${ }^{30}$ Hans Kelsen, Introduction to the Problems of Legal Theory: A Translation of the First Edition of the Reine Rechtslehre or Pure Theory of Law (translated by Bonnie Litschewski Paulson and Stanley L. Paulson; Oxford: Clarendon Press, 1997) 1; Kelsen, Pure Theory of Law (n 26) 1.

${ }^{31}$ Heinz Mayer, 'Reine Rechtslehre und Gemeinschaftsrecht' in Robert Walter, Clemens Jabloner, and Klaus Zeleny (eds), Hans Kelsen und das Völkerrecht (Vienna: Manz, 2004) 121.

${ }^{32}$ Hans Kelsen, 'The Pure Theory of Law, "Labandism", and Neo-Kantianism: A Letter to Renato Treves' in Stanley L. Paulson and Bonnie Litschewski Paulson (eds), Normativity and Norms: Critical Perspectives on Kelsenian Themes (reprint; Oxford: Clarendon Press, 2007) 173.

${ }^{33}$ Immanuel Kant, Critique of Pure Reason (1781/1787) A 10 / B 14-19.

${ }^{34}$ Henry Allison, Kant's Transcendental Idealism (rev. edn; New Haven: Yale University Press, 2004) 89-93.

${ }^{35}$ Hans Kelsen, Das Problem der Souveränität und die Theorie des Völkerrechts (Tübingen: Mohr-Siebeck, 1920) vi.
} 
However, such cognition of the law is only possible if one strictly adheres to the separation of 'Is' and 'Ought' and thereby eliminates from the object of legal cognition all alien elements and everything that is not strictly law, such as metaphysics, theology, politics, psychology, sociology, and ethics. ${ }^{36}$ More concretely, Kelsen emphasizes that the purity of a theory of legal cognition must be secured in two directions: firstly, it is to be secured against the 'Is' and 'the claims of a so-called "sociological" point of view,' and secondly it must also be 'secured against the claims of the natural law theory, which [...] takes legal theory out of the realm of positive legal norms and into the realm of ethico-political postulates. ${ }^{37}$ Law hence is, on the one hand, separate from morality as an act 'posited' by human beings, and therefore a positive 'Is'; but at the same time it is, on the other hand, also separate from fact by being obeyed, and if not obeyed, by being applied, which amounts to a normative 'Ought' ${ }^{38}$ In other words, the 'Ought' is irrevocably separated from the 'Is', and yet the former is to be treated as a descriptive 'Is', because of its posited nature. ${ }^{39}$

As a result, the validity of a given posited legal norm is not dependent on its substantive moral value or sociological facts, but rather on the formal procedures under which it has been created (and thus on the question whether it actually forms part of a given legal system ${ }^{40}$ ). In Kelsen's words, the reason for the validity of one given legal norm can only be the validity of another norm, ${ }^{41}$ and not its conformity with moral standards or empirical facts. According to the concept of the hierarchy of norms (Stufenbau der Rechtsordnung), which was first developed by Kelsen's colleague Adolf Julius Merkl and only later incorporated by Kelsen into his Pure Theory of Law, ${ }^{42}$ any given legal order - even the most primitive one where a chieftain wields absolute power - necessarily consists of at least two normative levels. The reason for this is that the very enthronization of said chieftain requires prior normative authorization. ${ }^{43}$

\footnotetext{
${ }^{36}$ Kelsen, Pure Theory of Law (n 26) 1.

${ }^{37}$ Hans Kelsen, Hauptprobleme der Staatsrechtslehre (2 ${ }^{\text {nd }}$ edn; Tübingen: Scientia, 1923) v.

${ }^{38}$ Hans Kelsen, 'On the Pure Theory of Law' (1966) 1 Israel Law Review 1, 2.

39 Wolfgang Meyer-Hesemann, 'Zur rechtstheoretischen Rekonstruktion der Reinen Rechtslehre' [1984] Rechtstheorie (Beiheft 5) 63, 66.

${ }^{40}$ Eugenio Bulygin, 'Das Problem der Geltung bei Kelsen' in Stanley L. Paulson and Michael Stolleis (eds), Hans Kelsen: Staatsrechtslehrer und Rechtstheoretiker des 20. Jahrhunderts (Tübingen: Mohr-Siebeck, 2005) 82-83.

${ }^{41}$ Kelsen, Pure Theory of Law (n 26) 198.

${ }^{42}$ Cf. inter alia, Martin Borowski, 'Concretized Norm and Sanction qua Fact in the Vienna School's Stufenbaulehre' (2014) 27 Ratio Juris 79, 79; and Stanley L. Paulson, 'On the Implications of Kelsen's Doctrine on Hierarchical Structure' (1996) 18 Liverpool Law Review 49, 49. Cf., however, also Luís Duarte d'Almeida, 'In Canonical Form: Kelsen's Doctrine of the "Complete" Legal Form' in Lúis Duarte d'Almeida, John Gardner, and Leslie Green (eds), Kelsen Revisited: New Essays on the Pure Theory of Law (Oxford: Hart Publishing, 2013) 276, drawing attention to differences in the use of the term 'norm' by Merkl and Kelsen.

${ }^{43}$ Adolf Julius Merkl, Die Lehre von der Rechtskraft entwickelt aus dem Rechtsbegriff (Leipzig/Vienna: Deuticke, 1923) 208-209, and fn 2; Adolf Julius Merk1, 'Gesetzesrecht und Richterrecht' in Hans R. Klecatsky, René Marcic, and Herbert Schambeck (eds), Die Wiener rechtstheoretische Schule: Schriften von Hans Kelsen, Adolf Merkl, Alfred Verdross, Band 2 (Vienna: Verlag Österreich, 2010) 1326.
} 
Therefore any legal order is necessarily ordered in a hierarchical manner and contains at least one level of 'absolute norm-creation' and one level of 'absolute norm-application', ${ }^{44}$ but more sophisticated legal orders usually possess more than two hierarchical levels of legal norms. It is typical of them to contain intermediate steps which - in Merkl's parlance - are determining as well as determined norms. These norms, however, do not stand side by side in an unrelated fashion, but depend on one another in a genetic relationship. ${ }^{45}$ And it is this connection, chain, or relation between determining norms (i.e. norms determining the creation and the reason of validity of lower norms) and determined norms (i.e. norms whose creation and validity is determined by higher norms) to which Merkl refers as the Delegationszusammenhang ${ }^{46}$ (which may roughly be translated as the chain of delegation or authorization). Thus, if an observer of the law intends to ascertain whether a given norm $\varphi$ (say, a contract between two individuals) forms part of the law or not, they only need to examine whether this norm was created in accordance with the relevant statutory rules on valid contracting. The question whether the respective statute is valid law, can then in turn be answered by way of scrutinizing whether it was created in accordance with the constitution. Thus it becomes quite easy to ascertain whether any given norm forms part of the law or not by way of gradually increasing individualization and concretization of the $\mathrm{law}^{47}$, if one starts at the apex of a legal order. The validity of the constitution itself is based on an older constitution, predating the one currently in force. Eventually we reach a constitution which is historically the first and which was laid down by a usurper, or by some kind of assembly. The validity of this very first constitution is the last presupposition, or final postulate, on which the validity of all norms of a given legal order depends. ${ }^{48}$ In epistemological terms, the hierarchy of norms is in that way capable of resolving the question whether a certain norm is a valid legal norm and thus part of a given legal order. ${ }^{49}$

\footnotetext{
${ }^{44}$ Adolf Julius Merkl, 'Das doppelte Rechtsantlitz' in Hans R. Klecatsky, René Marcic, and Herbert Schambeck (eds), Die Wiener rechtstheoretische Schule: Schriften von Hans Kelsen, Adolf Merkl, Alfred Verdross, Band 1 (Vienna: Verlag Österreich, 2010) 896; Merkl, 'Gesetzesrecht und Richterrecht' (n 43) 1325-1326; Merkl, Lehre von der Rechtskraft (n 43) 210.

${ }^{45}$ Jürgen Behrend, Untersuchungen zur Stufenbaulehre Adolf Merkls und Hans Kelsens (Berlin: Duncker \& Humblot, 1977) 16-17.

${ }^{46}$ Adolf Julius Merkl, 'Prolegomena einer Theorie des rechtlichen Stufenbaus' in Hans R. Klecatsky, René Marcic, and Herbert Schambeck (eds), Die Wiener rechtstheoretische Schule: Schriften von Hans Kelsen, Adolf Merkl, Alfred Verdross, Band 2 (Vienna: Verlag Österreich, 2010) 1098-1099.

${ }^{47}$ Hans Kelsen, Allgemeine Staatslehre (Berlin: Springer, 1925) 232-235.

${ }^{48}$ Kelsen, General Theory of Law and State (n 27) 115.

${ }^{49}$ Hans Tessar, Der Stufenbau nach der rechtlichen Autorität und seine Bedeutung für die juristische Interpretation (Vienna: Verlag Österreich, 2010) 42.
} 
But what lies beyond this historically first constitution? Where does its validity originate? Both Kelsen and Merkl certainly admit that the search for the reason of a norm's validity cannot go on indefinitely, like the search for the cause of an effect. ${ }^{50}$ Therefore, in order to avoid a regressus ad infinitum, this search is terminated by the highest norm, which represents the last reason of validity within a normative system. ${ }^{51}$ This highest norm is called the basic norm or Grundnorm, which - in a way similar to Frege's axiomatic foundation of logic ${ }^{52}$ or Kant's transcendental self ${ }^{53}$ - is presupposed and cannot be 'posited', i.e. it cannot be created by an authority whose competence to do so would have to derive from still a higher norm. Thus the basic norm is the common source for the validity of all norms belonging to a given legal order, ${ }^{54}$ and all norms whose validity can be traced back to one and the same basic norm form a normative system. It therefore constitutes, as one single source and in a dynamic manner, the bond between all the various norms of which an order consists. ${ }^{55}$ Epistemologically speaking, the Grundnorm is the Pure Theory's reply to the question of how we can cognize valid law in a fashion, similar to Kant's 'Copernican revolution' through which he realized that a priori (i.e. necessary) knowledge is not possible by conforming intuition to the nature of objects, but by conforming the object to our intuition. ${ }^{56}$ Equally, Kelsen remarks that legal cognition is only possible if said '[c] ognition itself creates its objects, out of materials provided by the senses and in accordance with its immanent laws. ${ }^{57}$ And that is why the Grundnorm constitutes the

\footnotetext{
${ }^{50}$ Kelsen, Pure Theory of Law (n 26) 194.

${ }^{51}$ Kelsen, General Theory of Law and State (n 27) 111; Merkl, Lehre von der Rechtskraft (n 43 ) 209 and 223 ; Merkl, 'Prolegomena einer Theorie des rechtlichen Stufenbaus' (n 46) 1091 and 1098.

${ }^{52}$ Cf. in particular Gottlob Frege, The Basic Laws of Arithmetic (translated by Montgomery Furth; Berkeley: University of California Press, 1964) 15; Gottlob Frege, 'Logic' in Hans Hermes et al. (eds), Gottlob Frege: Posthumous Writings (Chicago: University of Chicago Press, 1979) 126-127; Gottlob Frege, 'Thoughts' in Brian McGuinness (ed), Gottlob Frege: Collected Papers on Mathematics, Logic, and Philosophy (Oxford: Blackwell, 1984) 363. Gottlob Frege considered it crucial to regard the meanings with which logic is concerned as being independent from human beings and their psychological states and activities. Otherwise, logic would not be a set of necessary, but contingent laws. Therefore Frege regarded the method through which logical truths are justified as a case of logic justifying itself, and the question of why and how we can acknowledge a law of logic to be true can only be answered by reducing said law to another law of logic. And where this is not possible, logic can give no answer to that question.

${ }^{53}$ Kant, Critique of Pure Reason (n 33) B 131-134. The obscure notion of the transcendental self is best understood as always accompanying a subject's experiences and representations. In other words, whatever a person is thinking, there always is a subject of thought which can never be made an object. Cf. also Green, 'Hans Kelsen and the Logic of Legal Systems' (n 14) 392 and fn 119, wherein he compares this relationship between the transcendental self and the world it experiences to the relationship between the eye and the visual field. Nobody can see their own eye which is responsible for the visual field within the visual field. One could certainly hold up a mirror and then see something within the visual field that is rightly called 'this person's eye'. But the eye in the visual field is not the eye responsible for the visual field.

${ }^{54}$ Kelsen, Pure Theory of Law (n 26) 194-195.

${ }^{55}$ Kelsen, General Theory of Law and State (n 27) 111.

${ }^{56}$ Kant, Critique of Pure Reason (n 33) Preface to the Second Edition, xvii.

${ }^{57}$ Hans Kelsen, 'Natural Law Doctrine and Legal Positivism' (as an appendix) to Hans Kelsen, General Theory of Law and State (re-issue edn; New Brunswick/London: Transaction Publishers, 2007) 434.
} 
norm-creating and unifying force of the legal normative order ${ }^{58}$ by establishing a validityrelationship between these norms and by being the basis for the validity of all norms belonging to this order..$^{59}$

Subsequently, the decisive step for legal monism (or rather its strong version, in Hart's parlance) is, however, that there can only be one single Grundnorm for all bodies of law, including national and international law. Admittedly, jurists remain free to embrace a dualist or pluralist construction of the law which then becomes epistemologically and logically possible by way of two or more basic norms ${ }^{60}$ But this is only possible at the dear price of contaminating the purity of the law by reducing legal validity to factual-empirical criteria ${ }^{61}$ or of giving up the concept of legal validity and the legal nature of the international legal order altogether. The reason for this is that non-monist theories such as dualism or pluralism state that different legal orders are, prima facie, equally valid, either in entirely distinct (dualism) or overlapping spheres (pluralism). The principal problem with this view is, however, that in the case of normative conflicts between different bodies of law, one cannot understand both occurrences of 'valid law' as meaning exactly the same thing. Subsequently, when engaging with such a conflict, both dualism and pluralism make the mistake of using the term 'legal validity' whilst changing its meaning unnoticeably within the argument, ${ }^{62}$ thereby producing

\footnotetext{
${ }^{58} \mathrm{Cf}$. Uta Bindreiter, 'Presupposing the Basic Norm' (2001) 14 Ratio Juris 143, 147: 'the basic norm is the source of a dynamically grounded unity'; Behrend (n 45) 68-69: 'the basic norm constitutes the logical unity of the law'; Robert Walter, 'Entstehung und Entwicklung des Gedankens der Grundnorm' in Robert Walter (ed), Schwerpunkte der Reinen Rechtslehre (Vienna: Manz, 1992) 47: 'through the Grundnorm, the object of "positive law" achieves its unity'.

${ }^{59}$ Kelsen, Pure Theory of Law (n 26) 195.

${ }^{60}$ Michael Potacs, 'Das Verhältnis zwischen der EU und ihren Mitgliedstaaten im Lichte traditioneller Modelle' (2010) 65 Zeitschrift für Öffentliches Recht 117, 123; Theodor Schilling, 'Das Verhältnis zwischen Völkerrecht, Gemeinschaftsrecht und staatlichem Recht' in Stefan Griller and Heinz Peter Rill (eds), Rechtstheorie: Rechtsbegriff - Dynamik - Auslegung (Vienna/New York: Springer, 2011) 153-156; Griller, 'Völkerrecht und Landesrecht' (n 1) 87-88.

${ }^{61}$ Alfred Rub, Hans Kelsens Völkerrechslehre: Versuch einer Würdigung (Zurich: Schulthess Polygraphischer Verlag, 1995) 454.

${ }^{62}$ Cf. Green, 'Hans Kelsen and the Logic of Legal Systems' (n 14) 366-367. For example, an international legal norm could obligate a State to prohibit torture in any event, whilst the domestic law of the same State commands the national authorities to torture terrorist suspects, making joint obedience impossible. A dualist State might resolve the conflict in favour of national law, claiming that 'national interests have priority', thereby effectively denying the validity of the international norm in question. And a pluralist-minded State would most likely refrain from resolving the conflict all, which would subject the whole situation to a dilemma for the individuals involved. What both scenarios have in common is that legal validity must simply have a different meaning within the dualist and pluralist theories: in dualism, the validity of an international norm is denied in favour of national law on extralegal grounds, and thus the international legal norm is somehow 'less' valid than national law; in pluralism, the logical rule of non-contradiction would also demand a different meaning, since eventually one of the two norms would be applied arbitrarily, either by action (the national norm) or by omission (the international norm), but without any legal specification. This entails that the two legal norms in conflict are valid in a different sense without any legal grounding. Yet since 'legal validity' is equivalent with the very existence of a legal norm, the assumption of 'less' validity or simply a varying degree of validity is incommensurable with an objectively comprehensible analysis of the law.
} 
an equivocation in it. ${ }^{63}$ Hence dualists and pluralists should be well aware that what they are actually talking about may no longer be law. ${ }^{64}$ Thus the concept of legal monism protects the law from methodological arbitrariness ${ }^{65}$ and acts, through the Grundnorm, as a functional precondition of the legal science and thereby as an epistemological tool to outline its object of cognizance. ${ }^{66}$ In this vein, any construction other than monism will necessarily result in an equivocation or outright denial of the legal nature of international law, ${ }^{67}$ and a plurality of basic norms is - under these assumptions - consequently inconceivable. The ultimate conclusion of the postulate that the same ought to be cognized as the same ${ }^{68}$ is that, as Kelsen himself puts it, '[t]he unity of the epistemological standpoint demands imperiously a monistic view, ${ }^{69}$ and international law and national law form part of the same legal order under one common basic norm. ${ }^{70}$

Hart correctly summarizes that these claims can be reduced to the contention that all law forms a single system since there is a form of knowledge in the shape of legal cognition which studies both national and international law as subsumable under the single description "valid laws' and hence constitutes 'its object' as a unity. ${ }^{71}$ Hart, however, does not engage properly with Kelsen's use of Kant's unitary object of cognizance, and is to be criticized for brushing off this argument in one single sentence, stating: 'Surely we might as well attempt to deduce from the existence of the history of warfare or the science of strategy that all wars are one or all armies are one. ${ }^{72}$

\footnotetext{
${ }^{63}$ Cf. e.g., Maria J. Frápolli, 'Identity, Necessity, and Prioricity: The Fallacy of Equivocation' (1992) 13 History and Philosophy of Logic 91-109.

${ }^{64}$ Somek, 'Kelsen Lives' (n 28) 425.

${ }^{65}$ Stefan Hammer, 'Kelsens Grundnormkonzeption als neukantianische Erkenntnistheorie des Rechts?' in Stanley L. Paulson and Robert Walter (eds), Untersuchungen zur Reinen Rechtslehre (Vienna: Manz, 1986) 226.

${ }^{66}$ Robert Walter, 'Wirksamkeit und Geltung' (1961) 11 Zeitschrift für Öffentliches Recht 531, 539-540; Robert Walter, Der Aufbau der Rechtsordnung (2 ${ }^{\text {nd }}$ edn; Vienna: Manz, 1974) 13; Manfred Rotter, 'Die Reine Rechtslehre im Völkerrecht - eine eklektizistische Spurensuche in Theorie und Praxis' in Robert Walter, Clemens Jabloner, and Klaus Zeleny (eds), Hans Kelsen und das Völkerrecht (Vienna: Manz, 2004) 56.

${ }^{67}$ Somek, 'Kelsen Lives' (n 28) 425; Joseph G. Starke, 'Monism and Dualism in the Theory of International Law' (1936) 17 British Yearbook of International Law 66, 74.

${ }^{68}$ Jörg Kammerhofer, 'Kelsen - Which Kelsen? A Reapplication of the Pure Theory to International Law' (2009) 22 Leiden Journal of International Law 225, 234.

${ }^{69}$ Kelsen, Das Problem der Souveränität (n 35) 123.

${ }^{70}$ The question of which body of law - international law or national law - holds superior rank within this unified legal order is deliberately left unresolved at this point. This issue will be discussed and resolved in the subsequent section.

${ }^{71}$ Hart, 'Kelsen's Doctrine of the Unity of Law' (n 5) 564. Cf. also Kelsen, Pure Theory of Law (n 26) 328-329; Hans Kelsen, 'Die philosophischen Grundlagen der Naturrechtslehre und des Rechtspositivismus' in Hans R. Klecatsky, René Marcic, and Herbert Schambeck (eds), Die Wiener rechtstheoretische Schule: Schriften von Hans Kelsen, Adolf Merkl, Alfred Verdross, Band 1 (Vienna: Verlag Österreich, 2010) 250.

${ }^{72}$ Hart, 'Kelsen's Doctrine of the Unity of Law' (n 5) 565.
} 
Hart's objection fails for two reasons. First, Hart's argument does not work because his analogy of warfare does not work. Not only is it common sense that law and war are not relevantly similar, but it is also crucial to recall that Kelsen's legal monism flows from the logic of norms and the nature of normativity. As a consequence, there is no reason why Kelsen would be committed to a similar account where, because in warfare as an empirical fact, logic and normativity have no application. ${ }^{73}$ They would certainly apply to the law of warfare, but that is not what Hart means.

Second, Hart appears to misunderstand a particular element of Kantian philosophy, namely the unitary object of cognizance. To conceive of specific objects as a transcendental unity does not mean that these objects are all the same - this would be too simple a solution. What this unity entails is, in Kant's words, a 'productive synthesis ${ }^{74}$ of empirical data into one single concept. ${ }^{75}$ Kant's transcendental unity of apperception is the a priori ground of all concepts through which all of the manifold given in an empirical sensation is united into a concept of the object. ${ }^{76}$ In other words, all wars or all armies are not one in the same way as all laws are not one. But what is the same is the conceptual cognition of these objects, and their belonging to their respective unitary concept of 'war', 'army', or 'law'. The Second World War is not the same as the American Civil War, but they form a unitary object of cognizance 'war' by being observed as a large-scale armed conflict between different parties. Equally, the crime of murder is not the same as the crime of theft, but they both form part of the unitary object of cognizance 'law' by being cognized as part of an effective, self-creating, and coercive normative system which has been posited by human beings for the regulation of their behaviour. ${ }^{77}$ The essentiale of law ultimately is its validity which is coterminous with its very existence $^{78}$ and not subject to gradation. Either a specific legal norm is valid (and hence

\footnotetext{
${ }^{73}$ Giudice (n 9) 157.

${ }^{74}$ Kant, Critique of Pure Reason (n 33) A 118-119.

75 Ibid., A 250-215 and B 139. Cf. also Soon-U Hwang, Identitätsbewusstsein und Objektivität bei Kant (Würzburg: Königshausen \& Neumann, 2002) 52; Heinrich Lange, 'Der Begriff der Einheit in transzendentallogischer Bestimmung' (1972) 63 Kant-Studien 399-425.

${ }^{76}$ Kant, Critique of Pure Reason (n 33) B 139-140. Cf. also Henry E. Allison, Kant's Transcendental Deduction (Oxford: Oxford University Press, 2015) 229 and 356.

77 Cf. Heinz Mayer, Gabriele Kucsko-Stadlmayer and Karl Stöger, Grundriss des Österreichischen Bundesverfassungsrechts (1 $1^{\text {th }}$ edn; 2015) para 2, and Heinz Peter Rill, 'Internationales, supranationales und nationales Recht - eine Einheit' in Clemens Jabloner, Dieter Kolonovits, Gabriele Kucsko-Stadlmayer, Hans René Laurer, Heinz Mayer, and Rudolf Thienel (eds), Gedenkschrift Robert Walter (Vienna: Manz, 2013) 688; Clemens Jabloner, 'Der Rechtsbegriff bei Hans Kelsen' in Stefan Griller and Heinz Peter Rill (eds), Rechtstheorie: Rechtsbegriff - Dynamik - Auslegung (Vienna/New York: Springer, 2011) 23.

${ }^{78}$ Kelsen thus follows the philosophical tradition which denies that existence is an additional property or predicate of entities; cf. Aristotle, Metaphysics (ed. and transl. by Jonathan Barnes) 1028a 13-15; David Hume, A Treatise of Human Nature (1738) book I, part II, section VI; Kant, Critique of Pure Reason (n 33) A 600 / B 628; Bertrand Russell, 'On Denoting' (1905) 14 Mind 479-493; Gottlob Frege, Die Grundlagen der Arithmetik (Breslau: Koebner, 1884) $§ 53$.
} 
binding) and therefore exists, or it is invalid and therefore does not exist. ${ }^{79}$ This means that all law forms a unitary object of cognizance qua validity which derives from the Grundnorm as the very fount of this validity. The unity of the law can hence only be denied if one excludes the entire international legal order from the system of law. Only then would the two orders national and international law - be located on two completely different levels of cognition and the epistemological unity would disappear. ${ }^{80}$ The 'validity' of national law would then have a meaning different from the 'validity' of international law.

Third, Hart's implicit criticism that either Kelsen is right, but what he claims is trivially true and thus not interesting, or that Kelsen's claim is interesting but false, is also to be rejected. It might be correct to say that the way of how Kelsen reaches his epistemological conclusion on the basis of Kantian and neo-Kantian philosophy is terrifyingly trivial, ${ }^{81}$ because to claim that all law is law qua being law and thus forms 'one law' is necessarily true, but this would of course not be an interesting claim. Analytic a priori claims ('all bachelors are unmarried') are certainly always and trivially true and hence uninteresting. The decisive argument is, however, that Kelsen's claims are not analytic a priori, but synthetic a priori claims in the Kantian sense $^{82}$ and therefore not inevitably uninteresting due to their necessary nature. This means, alternatively put, that his claims entail propositions whose predicate concepts are not already contained in the respective subjects, ${ }^{83}$ or that certain interesting consequences follow from them which were not immediately perceptible. The most important consequence of these synthetic a priori claims is that only the presupposition of one single Grundnorm allows for the cognition of valid law, whilst the assumption of two (as in dualism) or more basic norms (as in pluralism) prevents such cognition. The reason for that is that assuming the existence of more than one basic norm will necessarily result in an equivocation of the meaning of 'legal validity', which would thereby destroy the very essence of the law. Furthermore, in contrast to dualism or pluralism, monism does not surrender when it comes to normative conflicts. Instead,

\footnotetext{
${ }^{79}$ Kelsen, Pure Theory of Law (n 26) 10; Hans Kelsen, 'Law and Logic' in Hans Kelsen, Essays in Legal and Moral Philosophy (selected and introduced by Ota Weinberg; Dordrecht: Reidel, 1973) 229. Cf. also Riccardo Guastini, 'The Basic Norm Revisited' in Lúis Duarte d'Almeida, John Gardner, and Leslie Green (eds), Kelsen Revisited: New Essays on the Pure Theory of Law (Oxford: Hart Publishing, 2013) 69, and Amedeo G. Conte, 'Hans Kelsen's Deontics' in Stanley L. Paulson and Bonnie Litschewski Paulson (eds), Normativity and Norms: Critical Perspectives on Kelsenian Themes (reprint; Oxford: Clarendon Press, 2007) 331-334.

${ }^{80}$ Kelsen, Das Problem der Souveränität (n 35) 124; Jochen von Bernstorff, The Public International Law Theory of Hans Kelsen (Cambridge: Cambridge University Press, 2010) 79-80.

${ }^{81}$ With regard to Kantian epistemology, cf. Allen Hazen, 'Logic and Analyticity' in Achille C. Varzi (ed), The Nature of Logic (European Review of Philosophy Vol. 4 (Stanford: CSLI Publications, 1999) 92.

${ }^{82}$ Cf. also William E. Conklin, The Invisible Origins of Legal Positivism: A Re-Reading of a Tradition (Dordrecht: Kluwer Law, 2001) 221; Marco Haase, Grundnorm - Gemeinwille - Geist (Tübingen: Mohr-Siebeck, 2004) 244245.

${ }^{83}$ Kant, Critique of Pure Reason (n 33) A 6-7 / B 10-11.
} 
monism rather asks: what will happen next? What is the legal significance of the two norms in question? If the other norm in question is not a legal norm at all, but a moral norm or political courtesy, the dichotomy of 'Is' and 'Ought' would certainly require that the legal norm be applied. And in contrast to dualism and pluralism which may attempt to resolve normative conflicts by taking recourse to extra-legal solutions, monism's subsequent question will always be: what will legally happen next? ? $^{84}$

This is exactly what is at stake in the question of whether the law forms one system or not, namely how the law is to be cognized and applied, and how lawyers can be enabled to resolve conflicts between legal norms. In sum, Hart's objection to the epistemological necessity of legal monism is mistaken and fails to convince on all grounds.

\section{The Conundrum of the Basic Norm}

Yet it is exactly this very basis of normativity in the Pure Theory of Law with which Hart also takes considerable issue: the Grundnorm. In Hart's own theory, the foundation of a legal system lies in the 'rule of recognition' which, as an accepted and practized social rule, provides the criteria for identifying all types of rules as rules and hence members of a given system. ${ }^{85}$ Thus, in contrast to the transcendental nature of the basic norm, the rule of recognition simply is a sociological and present matter of fact ${ }^{86}$ which can be expressed by utterances such as 'it is the law that ...' in the practice of courts, officials, and private persons. ${ }^{87}$ By establishing this extra-systemic foundation of the law on the basis of social practice, however, Hart unduly interfuses empirical facts and the normativity of the law and thereby transgresses the dichotomy of the 'Is' and 'Ought'. ${ }^{88}$ In Humean ${ }^{89}$ and Kelsenian terms, such derivation of legal norms

\footnotetext{
${ }^{84}$ Somek, 'Monism: A Tale of the Undead' (n 19) 354-355.

${ }^{85}$ Hart, The Concept of Law (n 8) 100. Cf. also Grant Lammond, 'The Rule of Recognition and the Foundations of a Legal System' in Luís Duarte D'Almeida, James Edwards, and Andrea Dolcetti (eds), Reading HLA Hart's The Concept of Law (Oxford: Hart Publishing, 2013) 98-102; Michael Pawlik, 'Der Rechtsbegriff bei H.L.A. Hart' in Stefan Griller and Heinz Peter Rill (eds), Rechtstheorie: Rechtsbegriff - Dynamik - Auslegung (Vienna/New York: Springer, 2011) 45-50.

${ }^{86}$ John Finnis, 'Revolutions and the Continuity of Law' in Alfred W.B. Simpson (ed), Oxford Essays in Jurisprudence: Second Series (Oxford: Clarendon, 1973) 55.

${ }^{87}$ Hart, The Concept of Law (n 8) 89 and 107. Cf. also Sylvie Delacroix, 'Hart's and Kelsen's Concepts of Normativity Contrasted' (2004) 17 Ratio Juris 501, 505; Raimo Siltala, A Theory of Precedent (Oxford: Hart Publishing, 2000) 223.

${ }^{88}$ Jean D'Aspremont, 'Herbert Hart in Today's International Legal Scholarship' in Jörg Kammerhofer and Jean d'Aspremont (eds), International Legal Positivism in a Post-Modern World (Cambridge: Cambridge University Press, 2014) 138-139; Jörg Kammerhofer, Uncertainty in International Law: A Kelsenian Perspective (London: Routledge, 2011) 208.

${ }^{89} \mathrm{Cf}$. Hume (n 78) book III, part I, section I: '[...] I am surprised to find [in every system of morality] that instead of the usual copulations of propositions, is, and is not, I meet with no proposition that is not connected with an ought, or an ought not. This change is imperceptible; but is however, of the last consequence. For as this ought, or ought not, expresses some new relation or affirmation, 'tis necessary that it should be observed and explained;
} 
from social practice is unacceptable, ${ }^{90}$ but - in the context of this section - need not bother us any further at this point.

What is more important is Hart's critique of the Grundnorm which he regards, when accepting the constitution as a living reality, as 'a needless reduplication to suggest that there is a further rule to the effect that the constitution (or those who "laid it down") are to be obeyed. ${ }^{91}$ This allegation of reduplication is based on the fact that the basic norm and the historically first constitution share two distinctive features, namely that both are effective and, as their validity is merely presupposed, non-valid. ${ }^{92}$ The constitution cannot be valid unless the Grundnorm is presupposed, since the constitution's validity depends on authorization by a superior norm; and the Grundnorm itself is also non-valid because if it were valid, there would be no need of presupposing its validity. ${ }^{93}$ In this light, Hart therefore does not see any added value in presupposing a transcendental basic norm if all it does is reduplicating the constitution on a higher and impalpable level. ${ }^{94}$

Before we now continue with the discussion, another related facet which has, so far, been deliberately been omitted, needs to be explained. When arguing in favour of monism, two different questions need to be distinguished: on the one hand, whether monism is correct (something that has now been established); and on the other hand, which body of law international law or national law - is superior within this unitary legal order in the case of normative conflict. It is exactly this latter aspect which still requires further elucidation. Kelsen formulates two versions of monism, namely monism under the primacy of national law and monism under the primacy of international law, ${ }^{95}$ which are both epistemologically and equally correct. The main difference between those two positions only is the location of the Grundnorm: if one assumes that national law has primacy, the basic norm is located in this

\footnotetext{
and at the same time that a reason should be given, for what seems altogether inconceivable, how this new relation can be a deduction from others, which are entirely different from it. But as authors do not commonly use this precaution, I shall presume to recommend it to the readers; and am persuaded, that this small attention would subvert all the vulgar systems of morality, and let us see, that the distinction of vice and virtue is not founded merely on the relations of objects, nor is perceived by reason.'

${ }^{90}$ Cf. Gerald J. Postema, Legal Philosophy in the Twentieth Century: The Common Law World (Dordrecht: Springer, 2011) 285.

${ }^{91}$ Hart, The Concept of Law (n 8) 246.

${ }^{92}$ Cf. Georg Henrik von Wright, Norm and Action. A Logical Enquiry (London: Routledge, 1963) 196 and 199, and Guastini, 'The Basic Norm Revisited' (n 79) 70. The term 'non-valid' (instead of 'invalid') is used here because it can be argued that both 'validity' and 'invalidity' are norm-relative concepts, that is, norms are invalid or valid only in relation to another norm permitting its issuing; thus the supreme norm of any given legal order is neither valid nor invalid, but non-valid.

${ }^{93}$ Guastini, 'The Basic Norm Revisited' (n 79) 70. Cf. also Kelsen, Pure Theory of Law (n 26) 201 et seq.

${ }^{94}$ Although the same objection holds, mutatis mutandis, against Hart's own rule of recognition; cf. Stephen Munzer, Legal Validity (The Hague: Martinus Nijhoff, 1972) 54.

${ }^{95}$ Kelsen, Pure Theory of Law (n 26) 339-344.
} 
particular body of law; and if one adheres to the primacy of international law, the basic norm is located in that body of law. Hence the decisive choice for one of them is not grounded in logic or epistemology, but ideology ('pacifism versus State sovereignty'), and therefore an objective legal science needs to keep a healthy distance from this choice in order to retain its purity. ${ }^{96}$ Whatever version of monism is eventually chosen is irrelevant to Kelsen; the crucial point is that dualism or pluralism are logically untenable.

Kelsen's 'choice hypothesis' was, however, heavily criticized by other members of the Vienna School of Jurisprudence, among them, most notably, Kelsen's own students, Alfred Verdross and Josef L. Kunz. ${ }^{97}$ Both disagree with the claim that lawyers might freely choose their preferred version of monism. In this light, they highlight that only monism under the primacy of international law is best equipped to describe and take into account the international legal order as it is; not only from a political view and the potential harm unrestricted State sovereignty can do to the international legal order, but also from a norm-logical perspective: at the end of the day, only the primacy of international law is able to guarantee the connection of the material of all positive rules of international law into one system, not the primacy of national law. Therefore, if one assumes a monist point of view, only the primacy of international law can place both bodies of law into a logically coherent framework. ${ }^{98}$

In line with Verdross and Kunz's criticism, the main argument of this paper also is that - in contrast to Kelsen's view - there are strong epistemological reasons in favour of monism under the primacy of international law. If one indeed accepts the primacy of national law, the principle of pacta sunt servanda would also be derived from national law. This would mean that every single State can, at any time, repeal the chain of delegation and thus the validity of international law. International law would consequently owe its legal character to national law and would merely be 'external State law' in the Hegelian sense that it is dependent on the will of the State and its choice whether or not to respect international norms. ${ }^{99}$ International law

\footnotetext{
${ }^{96}$ Ibid., 342-346. Cf. also Joseph G. Starke, 'The Primacy of International Law' in Salo Engel and Rudolf A. Métall (eds), Law, State, and International Legal Order (Knoxville: University of Tennessee Press, 1964$) 311$.

${ }^{97}$ Cf. generally Robert Walter, 'Die Rechtslehren von Kelsen und Verdross unter besonderer Berücksichtigung des Völkerrechts' in Robert Walter, Clemens Jabloner, and Klaus Zeleny (eds), Hans Kelsen und das Völkerrecht (Vienna: Manz, 2004) 40-42; von Bernstorff (n 80) 97-100.

${ }^{98}$ Cf. in particular Josef L. Kunz, 'On the Theoretical Basis of the Law of Nations' (1925) 10 Transactions of the Grotius Society 115, 139; Josef L. Kunz, 'La primauté de droit des gens' (1925) 6 Revue de droit international et de legislation comparée 556, 572 et seq.; Josef L. Kunz, Völkerrechtswissenschaft und Reine Rechtslehre (Leipzig: Deuticke, 1923) 82; Alfred Verdross, Die völkerrechtswidrige Kriegshandlung und der Strafanspruch der Staaten (Berlin: Engelmann, 1920) 33 et seq.; Alfred Verdross, 'Grundlagen und Grundlegungen des Völkerrechts' (1921) 29 Niemeyers Zeitschrift für Internationales Recht 65, 82-83.

${ }^{99}$ Georg Wilhelm Friedrich Hegel, Grundlinien der Philosophie des Rechts (1820) $§ \S 330$ et seq.
} 
therefore becomes a projection of national law, ${ }^{100}$ and the validity of every single treaty is grounded in the domestic legal act which authorizes the relevant State to conclude such treaties. Accordingly, every treaty has as many grounds of validity as there are parties to it. ${ }^{101}$ In a manner very similar to dualism, international obligations of States can, under this monist premise, only be self-imposed obligations, which can be unmade at any time by abolishing the respective municipal legal act authorizing the State to commit to said obligation. ${ }^{102}$ Strictly speaking, the term international 'obligations' thus becomes an oxymoron that can never be relied upon against the will of the State. ${ }^{103}$ This view obviously leads to a scenario of global anarchy where each State may refuse to be bound by international law and the very treaties it has concluded whenever its interests so dictate, ${ }^{104}$ and where two hundred-odd States would thus virtually construe two hundred-odd different international legal orders. The international legal order would only exist at the behest of the national legal orders and, most absurdly, there would be as many international legal orders as there are national legal orders. Such an utter denial of international law would not only be epistemologically impossible if one is committed to an objective meaning of the term 'legal validity', but also empirically false. ${ }^{105}$ In fact, it is common sense that the doctrine of State primacy is 'a denial of international law as law', 106 and must therefore be rejected, if one takes the notion of legal validity seriously. Today, nobody seriously endorses this version of monism anymore, ${ }^{107}$ and only monism under the primacy of international law is being accepted as a reasonable choice to theorize the relationship between municipal and international law under a monist premise. ${ }^{108}$

Yet even under this scenario, Hart considers a basic norm for international law to be a comic effort and an empty repetition of the rule that the society of States ought to observe certain standards of conduct as obligatory rules. ${ }^{109}$ According to Hart, Kelsen's suggested basic

\footnotetext{
${ }^{100}$ André Décencière-Ferrandière, 'Considérations sur le droit international dans ses rapports avec le droit de l'Etat' (1933) 40 Revue Générale de Droit International Public 8, 64-66.

${ }^{101}$ Max Wenzel, 'Der Begriff des Gesetzes in der Reichsverfassung' (1927) 4 Veröffentlichungen der Vereinigung der Deutschen Staatsrechtslehrer 136,141 et seq.

102 Georg Jellinek, Die rechtliche Natur der Staatenverträge (Vienna: Hölder, 1880) 9 et seq. and 46 et seq.

${ }^{103}$ Griller, 'Völkerrecht und Landesrecht' (n 1) 95.

${ }^{104}$ Edwin Borchard, 'The Relation between International Law and Municipal Law' (1940) 27 Virginia Law Review 137, 142.

105 Cf. also András Jakab, 'Kelsens Völkerrechtstheorie zwischen Erkenntnistheorie und Politik' (2004) 64 Zeitschrift für ausländisches öffentliches Recht und Völkerrecht 1045, 1051 fn 30.

106 Starke, 'Monism and Dualism in the Theory of International Law' (n 67) 77.

${ }^{107}$ Lando Kirchmair, Die Theorie des Rechtserzeugerkreises (Berlin: Duncker \& Humblot, 2013) 22-23.

108 Pierre-Marie Dupuy, 'International Law and Domestic (Municipal) Law' in Rüdiger Wolfrum (ed), Max Planck Encyclopedia of Public International Law (2 ${ }^{\text {nd }}$ edn; Oxford: Oxford University Press, 2013) para 12.

${ }^{109}$ Nota bene at this point that international law only takes up 'a relatively small and unimportant part' in Hart's theory; Hart, The Concept of Law (n 8) 4 and chapter X in general. Cf. also Mehrdad Payandeh, 'The Concept of International Law in the Jurisprudence of H.L.A. Hart' (2011) 21 European Journal of International Law 967,
} 
norm of international law, consuetudines sunt servandae, that is, States should behave as they have customarily behaved, says nothing more than that those who accept particular rules also ought to observe a rule that the rules ought to be observed. This is, again, a useless reduplication of the fact that a set of rules are accepted as binding by States as binding rules. ${ }^{110}$ In other words, Hart claims that Kelsen's Grundnorm of international law has no real informative content and hence goes no distance by that a distinct and system-constituting rule exists above what Hart would call primary rules of obligation at the international level.

Yet the problem is that Hart merely focuses on the abstractness of Kelsen's particular formulation of the basic norm, which makes him overlook its actual content. ${ }^{111}$ If we recall Kelsen's statement in this respect, he provides an account of a hierarchy of norms by stating that the basic norm of consuetudines sunt servandae allows for the development of customary international law as the first (and supreme) positive-legal stage within the international legal order. The customary rule of pacta sunt servanda then allows for the creation of treaties, which in turn, provides for the creation of treaty-based organizations and institutions. ${ }^{112}$ But this is exactly the same system-constituting normative hierarchy Hart is establishing on basis of his rule of recognition, albeit in a more elusive manner: ${ }^{113}$ even though this hierarchy of validity criteria is also characterized by an order of relative subordination and primacy, ${ }^{114}$ it remains rudimentary in comparison with Merkl and Kelsen's Stufenbau doctrine and fails to grasp all the rules which are considered as applicable and binding in a given legal order. ${ }^{115}$

Hart's allegation of emptiness and reduplication becomes even more erroneous when one notices that it is also easy to accuse his rule of recognition of the same charge, e.g. by formulating it as 'unless they are required to do otherwise by valid positive law, officials must apply as valid the norms of their own customary behaviour (and not, for example, norms of other people's customary behaviour, or moral norms, etc.).' ${ }^{116}$ Therefore it is no more accurate

967-968, referring to the 'shadowy existence of Hart's concept of international law'; D'Aspremont, 'Herbert Hart in Today's International Legal Scholarship' (n 88) 114, mentioning Hart's 'famous disdain for international law'. ${ }^{110}$ Hart, The Concept of Law (n 8) 230.

111 Giudice (n 9) 159.

112 Kelsen, General Theory of Law and State (n 27) 369-370; Kelsen, Pure Theory of Law (n 26) 214-217; Hans Kelsen, Principles of International Law (New York: Rinehart, 1952) 417-418.

${ }^{113}$ Uta Bindreiter, Why Grundnorm? A Treatise on the Implications of Kelsen's Doctrine (The Hague: Kluwer Law, 201) 69 fn 3.

${ }^{114}$ Hart, The Concept of Law (n 8) 105-107; this basically means that if certain rules have been identified as valid on the basis of a criterion and they then conflict with other rules which have been identified as being valid on the basis of another criterion, then the first validity criterion would prevail as superior.

${ }^{115}$ Michael Pawlik, Die Reine Rechtslehre und die Rechtstheorie H.L.A. Harts: Ein kritischer Vergleich (Berlin: Duncker \& Humblot, 1993) 155-156; Bindreiter, Why Grundnorm? (n 113) 69 fn 3. Cf. also Joseph Raz, The Authority of Law (2 $2^{\text {nd }}$ edn; Oxford: Oxford University Press, 2009) 150-151; Douglas Gerber, 'Levels of Rules and Hart's Concept of Law' (1972) 81 Mind 102-105.

116 Giudice (n 9) 159-160. 
to claim that Kelsen's attempt amounts to a meaningless reduplication than it would be to say that Hart's concept of the rule of recognition amounts to an empty reduplication. ${ }^{117}$

Yet besides Hart's theoretical attack on Kelsen's proposed basic norm of international law in the shape of consuetudines sunt servandae, there is also one major doctrinal difficulty with this particular content of the Grundnorm that needs to be discussed and resolved in order to support monism. The problem is that it puts customary international law at the top of the hierarchy of positive international law and thereby subordinates the entire international legal order to it. ${ }^{118}$ But since there is no formal hierarchy of sources in public international law, and hence all sources - treaties, custom, and general principles - rank as equal, ${ }^{119}$ no international lawyer could therefore accept that treaty law is somehow derived from custom. This assumption is hence not capable of describing and explaining the law as it is. Therefore one option to save Kelsen's concept of the basic norm of international law is to return to a Grundnorm without any content which merely sets out the transcendental conditions for a unified legal order: a terminus for the hierarchy of norms; the fount of the validity of all legal norms; and the unifying force of the legal order. Norm-creation, as Jörg Kammerhofer suggests, could then be explained by an explicit 'constitution of international law' or a 'historically first constitution' as a meta-meta-stratum above pacta sunt servanda and consuetudines sunt servandae as the meta-norms on law-creation. Although treaties, custom, and general principles would form separate branches of international law, ${ }^{120}$ they would be connected by this superstructure which regulates their interrelationship. This meta-metastratum would need to consist of positive norms, yet it remains doubtful whether such positive norms exist. $^{121}$

The most promising contender for this meta-meta-law of international law is Article 38 of the Statute of the International Court of Justice (hereinafter: ICJ Statute) as a manifestation

\footnotetext{
${ }^{117}$ Ibid., 160. Cf. also Jeremy Waldron, 'Who Needs Rules of Recognition?' in Matthew D. Adler and Kenneth E. Himma (eds), The Rule of Recognition and the U.S. Constitution (New York: Oxford University Press, 2009) 327-349 for a critical approach.

${ }^{118}$ For a graphical depiction of such a hierarchy cf. Marcelo Neves, 'Grenzen der Autonomie des Rechts in einer asymmetrischen Weltgesellschaft: Von Luhmann zu Kelsen' in Hauke Brunkhorst and Rüdiger Voigt (eds), Rechts-Staat: Staat, internationale Gemeinschaft und Völkerrecht bei Hans Kelsen (Baden-Baden: Nomos, 2008) 309.

${ }^{119}$ Notwithstanding ius cogens norms, there is no formal hierarchy among the sources of positive international law; cf. Article 38 of the Statute of the International Court of Justice, and Hugo Thirlway, The Sources of International Law (Oxford: Oxford University Press, 2014) 132-141; Jörg Kammerhofer, 'Hans Kelsen's Place in International Legal Theory' in Alexander Orakhelashvili (ed), Research Handbook on the Theory and History of International Law (Cheltenham: Edward Elgar, 2011) 98 et seq.

${ }^{120}$ Grigory Tunkin, 'Is General International Law Customary Law Only?' (1993) 4 European Journal of International Law 534, 536.

${ }^{121}$ Jörg Kammerhofer, 'Hans Kelsen's Place in International Legal Theory’ in Alexander Orakhelashvili (ed), Research Handbook on the Theory and History of International Law (Cheltenham: Edward Elgar, 2011) 152.
} 
of what is accepted as law-creating in international law. ${ }^{122}$ It remains uncertain, however, whether this provision is even of an actual epistemological value because there might be other sources of international law omitted in Article 38. ${ }^{123}$ Thus the enumeration of sources in this provision and its position as a meta-meta-law of international law is only correct if it corresponds to the number of meta-norms that actually exists, which means, a fortiori, that it is merely declaratory in nature. The reasoning behind Article 38 being declaratory is that it is generally accepted as such, and that the meta-norms on international law-creation (i.e. the sources of international law) are created by general acceptance. As a result, the real claim here is that the epistemological position of Article 38 arises from its correspondence with the metameta-law's condition for meta-law creation (i.e. general acceptance). ${ }^{124}$ It nonetheless remains doubtful whether Article 38 really constitutes such a meta-meta-law for international law, and international lawyers remain rather sceptical about this claim, in particular because of this provision's non-exhaustive character. ${ }^{125}$

The problem is that the assumed 'constitution' of international law either lacks positivity (i.e. it only exists in the minds of international lawyers) or perceptibility (i.e. it is positive, but simply very difficult to perceive due to its unwritten nature). ${ }^{126}$ It is, however, indisputable that there are certain constitutionalizing trends in international law, ${ }^{127}$ and therefore the latter view is much more plausible. There is a positive-legal constitution of international law which regulates international law-making, but due to its highly fragmented status, it is just very difficult to perceive. Yet fragmentation and difficulties in perceiving the elements of this constitution do not speak against its positive character - in the same way as the fragmented and

\footnotetext{
${ }^{122}$ Gerald Fitzmaurice, 'Some Problems Regarding the Formal Sources of International Law' in F.M. van Asbeck et al. (eds), Symbolae Verzijl. Présentées au Prof. J.H.W. Verzijl à l'occasion de son LXX-ième anniversaire (The Hague: Martinus Nijhoff, 1958) 173; Hugh Thirlway, International Customary Law and Codification (Leiden: Sijthoff, 1972) 36; Malcolm N. Shaw, International Law (7 $7^{\text {th }}$ edn; Cambridge: Cambridge University Press, 2014) 49. Cf. also Kammerhofer, Uncertainty in International Law (n 88) 209.

${ }^{123}$ Prakash Menon, 'An Enquiry into the Sources of Modern International Law' (1986) 64 Revue de droit international, de sciences diplomatiques et politiques 181, 182, arguing that Article 38 might not be exhaustive. Cf. also Clive Parry, The Sources and Evidences of International Law (Manchester: Manchester University Press, $1965)$ 109; Joost Pauwelyn, Conflict of Norms in Public International Law: How WTO Law Relates to Other Rules of International Law (Cambridge: Cambridge University Press, 2003) 90; Kammerhofer, Uncertainty in International Law (n 88) 209-210.

${ }^{124}$ Kammerhofer, Uncertainty in International Law (n 88) 210.

125 Ibid., 208. Cf. also Jörg Kammerhofer, 'International Legal Positivism' in Anne Orford and Florian Hoffmann (eds), The Oxford Handbook of the Theory of International Law (Oxford: Oxford University Press, 2016) 418.

${ }^{126}$ Jörg Kammerhofer, 'Uncertainty in the Formal Sources of International Law: Customary International Law and Some of Its Problems' (2004) 15 European Journal of International Law 523, 550.

${ }^{127}$ Cf. e.g., Thomas Kleinlein, 'Between Myths and Norms: Constructivist Constitutionalism and the Potential of Constitutional Principles in International Law' (2012) 81 Nordic Journal of International Law 79-132; Erika de Wet, 'The International Constitutional Order' (2006) 55 International and Comparative Law Quarterly 51-76; Oliver Diggelmann and Tilmann Altwicker, 'Is There Something Like a Constitution of International Law?' (2008) 68 Zeitschrift für ausländisches öffentliches Recht und Völkerrecht 623-650.
} 
mostly uncodified status of the United Kingdom's constitution does not speak against its constitutional nature. ${ }^{128}$ Besides Article 38 of the ICJ Statute, thus merely enumerating various sources of international law in a non-exhaustive manner, the meta-meta-norms of international law are complemented by various other sources on international-law creation, such as those rules of the 1969 Vienna Convention of the Law of Treaties on treaty-making, which are universally accepted; ${ }^{129}$ the relevant rules on the creation of customary international law, as explained by the ICJ in the North Sea Continental Shelf case; ${ }^{130}$ the gap-filling role of general principles to avoid the problem of non liquet ${ }^{131}$ certain types of unilateral declarations; ${ }^{132}$ and decisions of international organizations. ${ }^{133}$ Soft law, however, needs to be excluded from this list of international legal sources. The reason for this is that it lacks formally binding force, and given the strict binary character of the law as being either valid and existent or invalid and nonexistent, there is no room for a grey area of being 'a little valid' in between. ${ }^{134}$

Thus, at the end of the day, if one can accept Article 38 of the ICJ Statute and an unwritten and yet positive 'constitution' of international law as the meta-meta-law of the international legal order, there would be no need to bestow any duplicating content upon the Grundnorm as criticized by Hart, and it could remain the transcendental entity which it was originally envisaged to be. This Grundnorm would then constitute the reason for the validity of the quasiconstitution of international law, i.e. its meta-meta-law in the shape of Article 38 ICJ Statute plus other sources of international law-making, which sets out the conditions for law-creation,

\footnotetext{
${ }^{128}$ Cf. Joint Committee on Draft Civil Contingencies Bill, First Report; 28 November 2003, HL 184 HC 1074 , para 183, enumerating various sources and acts which could be taken to constitute the fundamental parts of British constitutional law. Against this view, cf. e.g., F.F. Ridley, 'There Is No British Constitution: A Dangerous Case of the Emperor's Clothes' (1988) 41 Parliamentary Affairs 340-361.

${ }^{129}$ Cf. International Law Commission, 'Fragmentation of International Law: Difficulties Arising from the Diversification and Expansion of International Law - Report of the Study Group of the International Law Commission, Finalized by Martti Koskenniemi', UN Doc. A/CN.4/L.682, 13 April 2006, para 493. Against this view, cf. e.g., Jan Klabbers, 'Setting the Scene' in Jan Klabbers, Anne Peters, and Geir Ulfstein (eds), The Constitutionalization of International Law (Oxford: Oxford University Press, 2009) 24. A remaining problem in this respect could be that those universally accepted rules on treaty law form part of customary international law, which would then place the latter above the former.

${ }^{130}$ North Sea Continental Shelf Cases (Germany v Denmark; Germany v the Netherlands) [1969] ICJ Reports 3 , para 77

${ }^{131}$ Prosper Weil, “"The Court Cannot Conclude Definitively...”: Non Liquet Revisited' (1997) 36 Columbia Journal of Transnational Law 109, 110; Hersch Lauterpacht, 'Some Observations on the Prohibition of Non Liquet and the Completeness of the Legal Order' in in F.M. van Asbeck et al. (eds), Symbolae Verzijl. Présentées au Prof. J.H.W. Verzijl à l'occasion de son LXX-ième anniversaire (The Hague: Martinus Nijhoff, 1958) 196 et seq. Cf. also, however, Legality of the Threat or Use of Nuclear Weapons (Advisory Opinion) [1996] ICJ Rep. 226, para 97, where the Court could not reach a definitive conclusion as to the legality or illegality of the use of nuclear weapons in extreme circumstances of self-defence.

${ }^{132}$ Nuclear Tests (Australia v France) [1974] ICJ Rep. 253, paras 48-56.

${ }^{133}$ Legal Consequences for States of the Continued Presence of South Africa in Namibia (South West Africa) Notwithstanding Security Council Resolution 276 (1970) (Advisory Opinion) [1971] ICJ Rep. 16.

${ }^{134}$ Cf. Jan Klabbers, 'The Redundancy of Soft Law' (1996) 65 Nordic Journal of International Law 167-182.
} 
i.e. the meta-law as constituted by the principles of pacta sunt servanda, consuetudines sunt servandae, etc.

In conclusion, Hart's criticism of Kelsen's theory of the Grundnorm cannot only be negatively rebutted, but can also serve as an excellent starting point to engage in a discussion which extensively and positively supports Kelsen's concept of the Grundnorm of international law, thus corroborating a monist view of the law.

\section{The Weak Version of Monism: The Principle of Validating Purport}

At the outset, it must be clearly emphasized again that Kelsen never distinguishes between a strong (i.e. necessary) and weak (i.e. contingent) version of monism. Let us nonetheless engage with Hart's criticism of Kelsen's 'principle of effectiveness' which, in Kelsen's words, legitimizes a coercive national legal order 'for the territory of its actual effectiveness as a valid legal order and the community constituted by this coercive order as a "State" in the sense of international law. ${ }^{135}$ Hart calls this chain of delegation between international and national law the relationship of validating purport, and argues that legal monism fails because it conflates this very relationship with the relationship of validation proper. Hart likens this to a fictitious situation wherein he writes a paper on Kelsen and concurrently receives a request from the Vice-Chancellor of Oxford University to write a paper on Kelsen. Hart concludes that without establishing the exact circumstances surrounding these two events, it remains impossible to ascertain whether he indeed obeyed the request or not. ${ }^{136}$ The central problem at stake is that of two different intentional states of mind: validation proper denotes a situation where a norm is adopted with the intent of creating it on the basis of another one, for instance when a judge identifies a particular norm as valid law on the basis of an accepted rule of recognition or if a national parliament adopts a legal act in accordance with the relevant constitutional procedures. Validating purport, conversely, means that legal norms which fit a certain description, are deemed valid regardless of whether they were created in order to become members of the legal order containing that description. ${ }^{137}$

To emphasize his criticism, Hart provides the hypothetical example of the British Parliament passing the Soviet Laws Validity Act which purports to declare all laws currently

\footnotetext{
${ }^{135}$ Kelsen, Pure Theory of Law (n 26) 210 and 336; Kelsen, General Theory of Law and State (n 27) 350-351. Cf. also Kelsen, Das Problem der Souveränität (n 35) 94-101.

${ }^{136}$ Cf. Hart, 'Kelsen's Doctrine of the Unity of Law' (n 5) 556.

${ }^{137}$ Somek, 'Kelsen Lives' (n 28) 426-427. Cf. also Hart, 'Kelsen’s Doctrine of the Unity of Law' (n 5) 561-562.
} 
effective in the Soviet Union to be valid within the United Kingdom. ${ }^{138}$ This does not, however, mean that British and Soviet law form one legal system, because it would be absurd to say that Soviet Law derives its validity from the relevant act of Parliament. Alternatively put, it is evident that the law of the Soviet Union is valid in the Soviet Union regardless of the validating purport of the British statute, since its validity is derived from an accepted rule of recognition in the Soviet Union. Hart continues that the same holds true for the relationship between international and national law. He states that questions regarding the formation of one single system and the derivation of validity of national law from international law (validation proper) are not the same as questions whether international law treats national law as forming part of a single system with itself and whether national law is valid according to international law on the basis of the principle of effectiveness. ${ }^{139}$ Since the principle of effectiveness is hence a mere expression of validating purport built into positive international law, unity between two bodies of law cannot be established if one of them recognizes as valid for itself what is valid in the other. It simply treats foreign rules in the same manner as its own rules, but it does not ingest these foreign rules. ${ }^{140}$

However, Hart's criticism cannot be sustained for three reasons. The first argument against Hart is his obvious misinterpretation of Kelsen. To begin with, it is very unlikely that Kelsen would have failed to appreciate and to acknowledge the distinction between validation proper and validating purport. In his works, Kelsen heavily emphasizes the distinction between objective and subjective legal meaning. The 'Ought' as the meaning of the norm may have a subjective dimension, i.e. it is treated as what someone wishes to be or not to be, for instance when somebody states in writing what ought to happen to their belongings after their passing. Hence the subjective meaning of this act is a testament. This, however, may not be sufficient, because from an objective viewpoint, it may not be a testament in the legal sense as some formalities were not observed. Thus the objective meaning denotes what ought to happen independently of what anyone wishes to be or not to be. ${ }^{141}$ After all, it is obvious that usurping

\footnotetext{
${ }^{138}$ In this respect, please note that Hart first published his paper on Kelsen in the year 1968 when the Soviet Union still existed. Cf. also fn 5 above.

${ }^{139}$ Hart, 'Kelsen's Doctrine of the Unity of Law' (n 5) 562-563.

${ }^{140}$ Somek, 'Monism: A Tale of the Undead' (n 19) 348; Somek, 'Kelsen Lives' (n 28) 427.

${ }^{141}$ Cf. Kelsen, Pure Theory of Law (n 26) 2-3 for this example; Kelsen, Introduction to the Problems of Legal Theory (n 30) 9-10; Kelsen, General Theory of Norms (n 24) 56-57. Cf. also Deryck Beyleveld and Roger Brownsword, 'Methodological Syncretism in Kelsen's Pure Theory of Law' in Stanley L. Paulson and Bonnie Litschewski Paulson (eds), Normativity and Norms: Critical Perspectives on Kelsenian Themes (reprint; Oxford: Clarendon Press, 2007) 117; Vinx, Hans Kelsen's Pure Theory of Law (n 10) 32-39; Bernard S. Jackson, 'Legal Semiotics and Semiotic Aspects of Jurisprudence' in Anne Wagner and Jan M. Broekman (eds), Prospects of Legal Semiotics (Dordrecht: Springer, 2010) 7.
} 
and abusing the authority of public offices, as the famous Hauptmann von Köpenick did, ${ }^{142}$ only satisfies the subjective, but not the objective meaning of the law, and that the lack of real legal authority results in the nullity of the alleged legal act. ${ }^{143}$ In the same vein Kelsen would certainly also have rejected Hart's idea that the Vice-Chancellor of Oxford University can put himself in a genuine position of normative authority over Hart by merely purporting to give orders to him. As a consequence, it is highly implausible to attribute to Kelsen a principle such as validating purport which involves an obvious confusion of objective and subjective legal. ${ }^{144}$

Furthermore, there is another aspect to this issue. Hart's distinction between validation proper and validating purport is of a substantive nature, which, however, is entirely beside the point to Kelsen's theory. Kelsen, as is well known, does not explore substance ('any kind of content might be law, ${ }^{145}$ ), but only the form in which the legal substance is to be accounted for by legal science. Prima facie, it is true that subjective purport may or may not play a role in law-creation. Individual parties, for example, can agree to enter into contractual relations through mere conduct which is not intended to create a norm. ${ }^{146}$ Furthermore, in constitutional legal terms, some processes of norm-creation might require some intentional use of a particular rule, ${ }^{147}$ but nevertheless, no law can be validly created by the authorized norm-creating body unless the relevant procedural rules are thoroughly complied with. Yet, what really matters in legal theoretical terms is that whether or not a relation of validation is based on - in Hartian terms - validation proper or sheer validating purport, it focuses on the particular substance of the legal norm in question. ${ }^{148}$ And this is clearly an issue with which Kelsen does not concern himself.

The second argument against Hart's criticism immediately follows from Kelsen's tacit rejection of the distinction between validating purport and validation proper. Hart's premise of 'weak monism' is only tenable under such a distinction, which he deems crucial to explain the phenomenon of 'system-relative validity', that is, the existence of several and different rules of recognition for different legal systems. ${ }^{149}$ At best, Hart's critique is very weak, as it rests on

\footnotetext{
${ }^{142}$ Wilhelm Voigt (1849-1922), an impostor who masqueraded as a military officer and, with the help of unsuspecting soldiers, occupied the local city hall of Berlin-Köpenick, where he 'confiscated' a considerable amount of money from the treasury.

${ }^{143}$ Hans Kelsen, 'Über Staatsunrecht' in Hans R. Klecatsky, René Marcic, and Herbert Schambeck (eds), Die Wiener rechtstheoretische Schule: Schriften von Hans Kelsen, Adolf Merkl, Alfred Verdross, Band 1 (Vienna: Verlag Österreich, 2010) 848. Cf. also Vinx, Hans Kelsen's Pure Theory of Law (n 10) 78-100.

${ }^{144}$ Vinx, 'The Kelsen-Hart Debate' (n 11) 4.

${ }^{145}$ Kelsen, Pure Theory of Law (n 26) 198.

146 Through an 'implied-in-fact contract' or acquiescence, for example.

${ }^{147}$ E.g. rules on required majorities in order to either pass constitutional or 'ordinary' statutes.

148 Somek, 'Kelsen Lives' (n 28) 428.

${ }^{149}$ Hart, 'Kelsen's Doctrine of the Unity of Law' (n 5) 575-576.
} 
a premise that Kelsen does not share; ${ }^{150}$ firstly because Kelsen cannot accept a social practice, such as Hart's rule of recognition, as a criterion for validity due to its transgression of the IsOught dichotomy; ${ }^{151}$ and secondly, because even if one substitutes 'rule of recognition' with Grundnorm, the idea of various different basic norms for different legal systems is incompatible with Kelsen's legal-epistemological foundations, ${ }^{152}$ as discussed above. Beyond that, the fact that Kelsen does not and cannot support the principle of validating purport also helps defend the viability of monism under the primacy of international law. The notion of monism under the primacy of international law claims that one must, under epistemological considerations, necessarily view national and international law as a unitary legal body in which international law is superior, and not, as Hart claims, because the principle of effectiveness purports to validate national law. ${ }^{153}$ Hart fails to acknowledge Kelsen's argument that the existence of a legal system - and thereby the defensibility of a certain construction of that legal system - depends on constraints of effectiveness. For Kelsen, it would not be scientific to postulate the existence of a particular legal order unless the behaviour it claims to govern also exhibits sufficient conformity with the norms of the system. ${ }^{154}$ The consequence is that monism under the primacy of international law has to be compatible with these constraints of effectiveness in order to amount to a viable description of the law. This is in fact the case and can easily be demonstrated by pointing out the existing system of States and other international legal subjects which interact with one another on a regular basis. Moreover, they do so in recognition of international law, such as that no State - despite the occasionally serious scepticism - seriously denies the legal quality of international law, ${ }^{155}$ and that international obligations are complied with ${ }^{156}$ lest States incur international responsibility and risk

\footnotetext{
150 Somek, 'Kelsen Lives' (n 28) 427.

${ }^{151}$ Uta Bindreiter, 'Presupposing the Basic Norm' (n 58) 166-168; Pawlik, Die Reine Rechtslehre und die Rechtstheorie H.L.A. Harts (n 115) 189-191; Kammerhofer, Uncertainty in International Law (n 88) 208. Cf. also Stanley L. Paulson, 'Faktum/Wert-Distinktion: Zwei-Welten-Lehre und immanenter Sinn: Hans Kelsen als Neukantianer' in Robert Alexy, Lukas H. Meyer, Stanley L. Paulson, and Gerhard Sprenger (eds), Neukantianismus und Rechtsphilosophie (Baden-Baden: Nomos, 2002) 223-251.

152 Theo Öhlinger, 'Die Einheit des Rechts: Völkerrecht, Europarecht und staatliches Recht als einheitliches Rechtssystem?' in Stanley L. Paulson and Michael Stolleis (eds), Hans Kelsen: Staatsrechtslehrer und Rechtstheoretiker des 20. Jahrhunderts (Tübingen: Mohr-Siebeck, 2005) 162-163.

${ }^{153}$ Cf. Hart, 'Kelsen's Doctrine of the Unity of Law' (n 5) 563.

${ }^{154}$ Vinx, 'The Kelsen-Hart Debate' (n 11) 5-6. Cf. also Kelsen, Das Problem der Souveränität (n 35) 94-101; and Kelsen, Principles of International Law (n 112) 412-414.

${ }^{155}$ Chittharanjan F. Amerasinghe, 'Theory with Practical Effects: Is International Law neither Fish nor Fowl? Reflections on the Characterization of International Law' (1999) 37 Archiv des Völkerrechts 1, 1; Jan Wiegandt, 'Internationale Rechtsordnung oder Machtordnung?' (2011) 71 Zeitschrift für ausländisches öffentliches Recht und Völkerrecht 31, 75.

${ }^{156}$ Cf. James L. Brierly, 'The Basis of Obligation in International Law' in Hersch Lauterpacht and Humphrey Waldock (eds), The Basis of Obligation in International Law and Other Papers by the Late James Leslie Brierly (Oxford: Clarendon, 1958) 1-67; Myres McDougal, Harold Lasswell, and Michael Reisman, 'Theories about
} 
subsequent sanctions. Hart is therefore wrong in assuming that monism under the primacy of international law depends on nothing but a relation of validating purport between the principle of effectiveness and national law, and he fails to make the case that monism cannot account for State behaviour in a descriptively plausible way. ${ }^{157}$

The last argument against Hart's criticism is that legal monism is in fact able to accommodate the example of the Soviet Laws Validity Act quite well, since Hart fails to take into account one of the most crucial elements of the Pure Theory of Law: the Stufenbau doctrine. Hart is absolutely right in saying that the purported validation of Soviet Law by the Soviet Laws Validity Act is not really what validates Soviet Law (except for its use in British courts, but this is a question of the conflict of laws). ${ }^{158}$ Yet Hart commits to an obvious non sequitur when assuming that it follows from the fact that the Soviet Laws Validity Act does not validate Soviet Law, that British and Soviet Law cannot possibly form part of one and the same legal order. If jurists take the viewpoint of monism under the primacy of international law, they can certainly argue that both British and Soviet Law form part of one legal order as they are both delegated by the principle of effectiveness under international law, and not by a validating relationship between British and Soviet Law. ${ }^{159}$ This makes perfect sense, if we remember the hierarchy of norms as originally devised by Merkl, according to which only superior norms can validate inferior norms, but legal norms of the same hierarchical level cannot validate one another. ${ }^{160}$ Therefore in a monist construction under the primacy of international law, where British and Soviet Law are located on an equal level of legal hierarchy, the Soviet Laws Validity Act, as a British legal act, can never be an authentic validation of Soviet law. ${ }^{161}$ Monism does not claim that one national legal order validates another national legal order, and Hart fails in comparing the horizontal relationship between equal bodies of law (i.e. national law) with the vertical relationship between hierarchically different bodies of law (i.e. international law as the delegating and national law as the delegated body of law, respectively).

In sum, Hart's critique must therefore be rejected.

International Law: Prologue to a Configurative Jurisprudence' (1968) 8 Virginia Journal of International Law 188-299; Rosalyn Higgins, Problems and Process (Oxford: Clarendon, 1994) 13-16.

${ }^{157}$ Vinx, 'The Kelsen-Hart Debate' (n 11) 6.

${ }^{158}$ Hart, 'Kelsen's Doctrine of the Unity of Law' (n 5) 562.

159 Vinx, 'The Kelsen-Hart Debate' (n 11) 4.

${ }^{160}$ Cf. Merkl, Die Lehre von der Rechtskraft (n 43) 217; Merkl, 'Prolegomena einer Theorie des rechtlichen Stufenbaus' (n 46) 1098-1099; Kelsen, General Theory of Law and State (n 27) 123-124; Kelsen, Pure Theory of Law (n 26) 233-234.

${ }^{161}$ Vinx, 'The Kelsen-Hart Debate' (n 11) 4. 


\section{JOSEPH RAZ AND THE IDENTITY OF LEGAL SYSTEMS}

Joseph Raz is the other legal theorist besides Hart who has critically engaged with Kelsen's theory and his monist claim. In doing so, Raz formed very strong opinions and explicit views on Kelsen which he follows through and defends with an impressive philosophic will. And although he somewhat rehabilitates Kelsen's reputation by defending him against Hart on the basis of the strength and robustness he sees in Kelsen's writings, ${ }^{162}$ Raz is nonetheless of the opinion that Kelsen errs in stipulating the Grundnorm as an epistemological requirement at the apex of the legal order in order to bestow unity on it. ${ }^{163}$ In concreto, Raz argues that the reason why a basic norm is not necessary for the unity of the legal system can be easily understood by examining the following two cases: (1) there are non-identical legal orders which share a Grundnorm; and (2) even without the Grundnorm, a unified legal order is possible. ${ }^{164}$ As will become clear in the analysis below, the first argument refers to the hierarchy of norms and the chain of delegation, whilst the second argument deals with the basic norm itself. It will also become evident that Raz further developed the arguments by Hart, and that they are, for this reason, fairly similar. ${ }^{165}$ And yet for the same reason Raz's criticism must fail, as it ends up misunderstanding and misconstruing Kelsen's theory. ${ }^{166}$

\section{Chains of Validity and the Identity of Legal Orders}

At the outset, Raz offers a reconstruction of the most basic tenets of Kelsen's theory in the form of two (in his opinion: flawed) axioms from which two further theorems can be derived. For the purposes of the present section, only the first axiom is relevant which reads as follows: 'Two laws, one of which directly or indirectly authorizes the creation of the other, belong to the same legal system.' From this, Raz derives the theorem that 'if one law authorizes the creation of another or if both are authorized by a third law, then both belong to the same legal system. ${ }^{, 167}$ Thereby this axiom and theorem introduce the concept of a chain of validity. Raz, however, emphasizes that they also demonstrate the flaws in Kelsen's theory: the derived

\footnotetext{
${ }^{162}$ Cf. e.g., Joseph Raz, 'Two Views of the Nature of the Theory of Law: A Partial Comparison' (1998) 4 Legal Theory 249-282; Joseph Raz, 'Kelsen's Theory of the Basic Norm' (1974) 19 American Journal of Jurisprudence 94-111; Raz, The Concept of a Legal System (n 6) 147-167.

${ }^{163}$ Kletzer, 'The Role and Reception of the Work of Hans Kelsen in the United Kingdom' (n 22) 158.

${ }^{164}$ Raz, The Concept of a Legal System (n 6) 100-106; Raz, 'Kelsen's Theory of the Basic Norm' (n 162) 95.

165 Vinx, 'The Kelsen-Hart Debate' (n 11) 1 fn 3.

166 Delacroix (n 87) 519; Kletzer, 'The Role and Reception of the Work of Hans Kelsen in the United Kingdom' (n 22) 158.

${ }^{167}$ Raz, 'Kelsen's Theory of the Basic Norm' (n 162) 95.
} 
theorem is false as the fact that two norms are linked by a chain of delegation (or validity) is in itself insufficient to guarantee that they in fact belong to the same legal order. And if the derived theorem is false, so must be the axiom from which it has been derived by way of modus tollens. ${ }^{168}$

Raz presents a simple example to illustrate his claim that the Grundnorm cannot be the decisive criterion for the unity of a given legal order, as it is possible to conceive of nonidentical legal orders sharing a basic norm. If the first axiom - asserting that all the laws belonging to one chain of validity are part of one and the same legal order - were indeed true, the peaceful granting of independence to new States would be impossible. ${ }^{169}$ Raz asks to imagine that country A has a colony B, and that both territories are governed by the same legal order. Now imagine that the 'motherland' A grants independence to B on the basis of a law that confers exclusive and unlimited legislative powers over B to an assembly or parliament elected by the residents of B. ${ }^{170}$ Eventually, suppose that this assembly or parliament adopts a constitution which is generally recognized by the residents of B. Subsequently, elections are held and further laws are adopted according to this constitution, and quite naturally, the government, courts, and the population of B regard themselves as an independent State with an independent legal order. ${ }^{171}$ And not only has this new State been recognized by all other States including A, the courts of A also regard the constitution and laws of B as a separate legal order distinct from their own. ${ }^{172}$ And yet, despite all these facts, Raz highlights, it follows from Kelsen's first axiom that the constitution and laws of B are part of the legal order of A, since all laws of B were authorized by the independence-granting law of $\mathrm{A}$ in the first place and therefore belong to the same chain of validity and to the same legal order. ${ }^{173}$ This proves that the 'basic norm cannot play the role assigned to it by Kelsen's criteria of membership and identity, and, hence, that these criteria fail to fulfil their function.' ${ }^{174}$

\footnotetext{
168 Vinx, Hans Kelsen's Pure Theory of Law (n 10) 185.

${ }^{169}$ Raz, The Concept of a Legal System (n 6) 102-103; Raz, 'Kelsen's Theory of the Basic Norm' (n 162) 98.

${ }^{170}$ For the more complex question of a revolutionary and unpeaceful transfer of powers, cf. Raz, The Concept of a Legal System (n 6) 103. Cf. also the practical impact of this question on the Rhodesian Unilateral Declaration of Independence of 1965 in case Madzimbamuto v. Lardner-Burke [1969] AC 645 (PC) and its analysis in e.g., T.C. Hopton, 'Grundnorm and Constitution: The Legitimacy of Politics' (1978) 24 McGill Law Journal 72-91; and F.M. Brookfield, 'The Courts, Kelsen, and the Rhodesian Revolution' (1969) 19 The University of Toronto Law Journal 326-352.

${ }^{171}$ Raz, The Concept of a Legal System (n 6) 102-103; Raz, 'Kelsen's Theory of the Basic Norm' (n 162) 98.

${ }^{172}$ As the United Kingdom did with respect to its Commonwealth Realms in the Statute of Westminster 1931, 22-

23 Geo. 5 c. 4. Cf. also Benjamin Spagnolo, The Continuity of Legal Systems in Theory and Practice (Oxford: Hart Publishing, 2015) 35-36.

${ }^{173}$ Raz, 'Kelsen's Theory of the Basic Norm' (n 162) 98.

${ }^{174}$ Raz, The Concept of a Legal System (n 6) 104.
} 
Nevertheless, Raz's argument is not as stringent as it seems prima facie. To begin with, Raz fails to see that what Kelsen has in mind when he talks about the unity of a legal order is not a sociological, historical, or political conception of unity, but a legal-normative conception. Kelsen postulates that only norms belonging to one and the same legal order can be valid, and hence the claim that the law of both A and B are valid is the same as claiming that both belong to one and the same legal order. ${ }^{175}$ However, Kelsen is not committed to the claim that it is merely a law enacted in A, purporting to authorize the constitutional system of $\mathrm{B}$, that establishes a chain of validity between A and B. Purported chains of validity are only legally significant if jurists in country B do not opt for their State's normative independence. But as already explained above with respect to Hart's critique, Kelsen never assumes that there is a direct and immediate chain of delegation between different States (i.e. regardless of international law), and therefore jurists in B need not adopt the perspective of absolute normative independence in order to avoid a chain of validity between A and B. ${ }^{176}$

The second option to rebut Raz's argument and to show that there is no chain of validity is to regard both the laws of $\mathrm{A}$ and $\mathrm{B}$ as parts of the overarching international legal order qua monism. ${ }^{177}$ Even if one adopts a monist view under the primacy of national law, the conclusion that there is only one legal order is inevitable. In this scenario, the basic norm would be located at the apex of A's legal order. Then the validity of B's constitution would be grounded in a norm of A's constitution, either directly granting validity to the laws of B (which would confirm Raz's critique, however), or granting validity to international law which in turn delegates the laws of B. Yet seeing, that monism under the primacy of national law is not only practically, but also epistemologically absurd, it is much more plausible to start off from the perspective of monism under the primacy of international law. In this case, the chain of validity would arise from the basic norm of international law authorizing the positive rules of international law which in turn authorize, under the principle of effectiveness, the constitutions of both A and B. ${ }^{178}$ Reliance on the principle of effectiveness therefore has the advantage of explaining why the relationship of validating purport between the two States is entirely irrelevant with regard to the validity of the laws of B. Once B became independent, it achieved effective control of its territory and hence, under the principle of effectiveness, only remains

\footnotetext{
${ }^{175}$ Kletzer, 'The Role and Reception of the Work of Hans Kelsen in the United Kingdom' (n 22) 159. Cf. Kelsen, Pure Theory of Law (n 26) 221 et seq.; Kelsen, General Theory of Law and State (n 27) 110-111; Kelsen, Principles of International Law (n 112) 408 et seq.

176 Vinx, Hans Kelsen's Pure Theory of Law (n 10) 187.

177 Ibid.

${ }^{178}$ Kletzer, 'The Role and Reception of the Work of Hans Kelsen in the United Kingdom' (n 22) 159.
} 
delegated by the international legal order, not A. And since B is neither connected to A via a chain of delegation nor normatively independent from international law, Raz's claim that Kelsen's alleged axiom and theorem are false is to be rejected. Kelsen and Merkl's theory of the chain of delegation simply does not lead to the counter-intuitive example Raz imputes to it. $^{179}$

\section{Again: The Basic Norm}

Raz's second element of criticism introduces the second axiom of Kelsen's theory which states that 'all the laws of a legal system are authorized directly or indirectly by one law' from which Raz derives the theorem that 'two laws, neither of which authorizes the creation of the other, do not belong to the same system unless there is a law authorizing the creation of both. ${ }^{180}$ In this vein, this axiom and theorem give rise to the notion of the Grundnorm, which Raz equally considers flawed. Even without Kelsen's hypothesized basic norm, Raz says, a legal order can be unified, and therefore the theorem is false. And if the theorem is false, so is its respective axiom. $^{181}$

In order to demonstrate his claim, Raz uses the example of a 'legally minded observer' coming to a country where laws can derive their validity either from a written constitution or a customary constitution. ${ }^{182}$ This observer will subsequently wonder whether the codified and the customary constitutions belong to the same legal order. To answer this question, Kelsen would refer the observer to the Grundnorm, and reply that since neither of the constitutions depends on the other, and since there is no superior positive law which could delegate them, the two constitutions can only be authorized by one and the same basic norm. Ergo they belong to the same legal order. For Raz, however, this method represents a petitio principii, as he regards the basic norm mainly as a power-conferring norm, that is, as authorizing normcreation. ${ }^{183}$ And to identify the relevant authorizing content of the basic norm, according to

\footnotetext{
${ }^{179}$ Alida Wilson, 'Joseph Raz on Kelsen's Basic Norm' (1982) 27 American Journal of Jurisprudence 46, 62; Vinx, Hans Kelsen's Pure Theory of Law (n 10) 187-188.

${ }^{180}$ Raz, 'Kelsen's Theory of the Basic Norm' (n 162) 95.

${ }^{181}$ Raz, The Concept of a Legal System (n 6) 100-106; Raz, 'Kelsen's Theory of the Basic Norm' (n 162) 95. Cf. also Vinx, Hans Kelsen's Pure Theory of Law (n 10) 185.

${ }^{182}$ Cf. Kelsen, General Theory of Law and State (n 27) 125 where Kelsen explicitly mentions the United Kingdom as having 'no "written" and hence no formal constitution'. Nonetheless 'the (material) constitution has the character of customary law [...].'

${ }^{183}$ Raz, The Concept of a Legal System (n 6) 66 and 147 et seq., contrasting power-conferring with duty-imposing norms. Cf. also Stanley L. Paulson, 'Die unterschiedlichen Formulierungen der "Grundnorm"' in Aulis Aarnio, Stanley L. Paulson, Ota Weinberger, Georg Henrik von Wright, and Dieter Wyduckel (eds), Rechtsnorm und Rechtswirklichkeit (Berlin: Duncker \& Humblot, 1993) 59 and 64-67, discussing the Grundnorm in its function as a 'norm-creating authorization rule'.
} 
Kelsen, one must identify 'the facts through which an order is created and applied.' ${ }^{184}$ Yet this will drive the observer to despair, because then he or she would only be able to identify the legal order with the help of the basic norm, whilst the basic norm can only be identified after the identity of the legal has been established. Therefore, the Grundnorm represents a vicious cycle and cannot solve the problem of identity and unity of legal orders. ${ }^{185}$

As a first step, one could counter this argument with reference to the Pure Theory's epistemological a priori truth that the customary constitution and the codified constitution cannot fail to belong to the same legal order if they are both valid law. ${ }^{186}$ Thus, the question whether the codified or the customary constitution belong to the same legal order or whether there are actually two distinct legal orders in force is not problematic for the Kelsenian legally minded observer once it is generally admitted that both are valid law. In this vein, it does not make sense to criticize Kelsen for not providing a criterion to answer this question. ${ }^{187}$

The problem is that a sceptic will not be convinced by the epistemological force of the Pure Theory of Law. As a second step, one could therefore take recourse, as suggested by Vinx, to our fictional protagonist, the Kelsenian law-abiding person. ${ }^{188}$ The interest of such a person would be to determine what the law requires, and in order to do so, this person must presuppose the Grundnorm to cognize the normative nature of the law. Even an anarchist, according to Kelsen, could describe the law as a system of valid and behaviour-regulating norms without having to approve of this law. ${ }^{189}$ Although Raz criticizes this element in Kelsen's theory as a moral statement and thus an impurity, he eventually accepts the role of the basic norm as a means for the jurist to pretend that law is a valid system of norms. ${ }^{190}$ Persisting differences in this respect aside ${ }^{191}$ and in the context of the present analysis, we can consequently agree that both Kelsen and Raz would accept such a fictitious law-abiding person. From an empirical point of view, this person could find that both the customary and the codified constitution are considered to be valid by large groups of members of society, and that he or she must therefore

\footnotetext{
${ }^{184}$ Kelsen, General Theory of Law and State (n 27) 120.

${ }^{185}$ Raz, 'Kelsen's Theory of the Basic Norm' (n 162) 99.

${ }^{186}$ Cf. Kelsen, Pure Theory of Law (n 26) 328-329.

187 Vinx, Hans Kelsen's Pure Theory of Law (n 10) 189. Cf. also Juan Antonia García Amado, 'Grundnorm und Gewohnheitsnorm bei Kelsen' in Stanley L. Paulson and Michael Stolleis (eds), Hans Kelsen: Staatsrechtslehrer und Rechtstheoretiker des 20. Jahrhunderts (Tübingen: Mohr-Siebeck, 2005) 100; Norberto Bobbio, 'Kelsen and Legal Power' in Stanley L. Paulson and Bonnie Litschewski Paulson (eds), Normativity and Norms: Critical Perspectives on Kelsenian Themes (reprint; Oxford: Clarendon Press, 2007) 446.

188 Vinx, Hans Kelsen's Pure Theory of Law (n 10) 189-190.

${ }^{189}$ Kelsen, Pure Theory of Law (n 26) 218 fn 82

${ }^{190}$ Cf. generally Joseph Raz, 'The Purity of the Pure Theory' (1981) 35 Revue internationale de philosophie 441459.

${ }^{191}$ For an in-depth critical discussion of Raz's view of normativity in Kelsen's theory cf. also e.g. Wilson (n 179) 46-63; Bindreiter, Why Grundnorm? (n 113) 90-95; and Delacroix (n 87) 512-518.
} 
comply with both. Potential conflicts between the two constitutions, however, must somehow be resolved, which is only possible by presuming a content of the Grundnorm which makes joint compliance possible. Thereby both custom and codified law become normatively coordinated parts of the same hierarchy of norms, and the question whether there is one or whether there are two legal orders can never become a serious issue for the law-abiding person. ${ }^{192}$ Nonetheless, a Razian sceptic could, at this point, simply reiterate their critique that this assumption is begging the question, since to claim that there must be a possibility to comply with both custom and statute because of their being valid is only possible if we already know that they both form part of the same legal order. What is required here is an independent criterion to resolve the issue of identity before the appeal to joint compliance is made. ${ }^{193}$

Thus, if we examine the relationship between international and national law, it becomes clear that a practice-based criterion, according to which the observer would simply opt for the validity of that body of law which enjoys a higher degree of effectiveness, would not work to establish the unity of the law. Kelsen himself acknowledges that there are no international lawapplying institutions whose practice of recognition could provide for such a criterion. ${ }^{194}$ The same applies by analogy to the example of the two constitutions. Vinx argues that if we assume instances of disagreement among the members of society and its legal practitioners as to whether there is a normative relation between the customary and the codified constitution, it is possible to imagine that some members of society or the jurists believe, while others deny that both constitutions are valid. Equally, one can imagine that both society and jurists agree that both are valid, while they disagree with respect to the nature of the normative relationship between them. It is exactly this example where practice-based or institutional criteria fail to provide a conclusive answer to the question of identity and unity of the law. But a solution could be found in the behaviour of the law-abiding person: if we presuppose the effectiveness of both constitutions, this law-abiding person will necessarily be biased towards construing the broadest possible set of effective rules as parts of one legal order. Thus to deny a norm membership in the legal order would be tantamount to denying its legal validity. Yet since this

\footnotetext{
${ }^{192}$ Vinx, Hans Kelsen's Pure Theory of Law (n 10) 190. Cf. also Kelsen, Das Problem der Souveränität (n 35) 94 fn 1; Hans Kelsen, 'Reichsgesetz und Landesgesetz nach österreichischer Verfassung' (1914) 32 Archiv des öffentlichen Rechts 202, 211; Amado (n 187) 104.

${ }^{193}$ Vinx, Hans Kelsen's Pure Theory of Law (n 10) 190.

${ }^{194}$ Kelsen, Principles of International Law (n 112) 269-270; Kelsen, General Theory of Law and State (n 27$) 339$. Nonetheless Kelsen definitely regards the then-emerging international judiciary as a first step towards such an international institution; cf. Hans Kelsen, The Legal Process and International Order (London: Constable, 1935); Hans Kelsen, Peace through Law (Chapel Hill: University of North Carolina Press, 1944) 16; and Mary Ellen O'Connell, 'The Natural Superiority of Courts' in Ulrich Fastenrath et al. (eds), From Bilateralism to Community Interest: Essays in Honour of Judge Bruno Simma (Oxford: Oxford University Press, 2011) 1041-1042.
} 
person is interested in upholding the effects of the law, he or she will avoid this validityannulling conclusion whenever possible ${ }^{195}$ - in the same way as authorities interpret customary norms in accordance with the set of positive norms and vice versa in order to make them applicable without any normative conflicts. ${ }^{196}$ As a result, Vinx concludes, the law-abiding person will base their judgments regarding the structure of the legal order in question on hypotheses that cannot be fully explained in terms of sociological or empirical observation. Once one adopts the perspective of law-abidingness, Raz's allegation of circularity does not apply anymore, as this allegation presupposes agreement on the point that a satisfactory account of the identity of legal orders must be one that appeals to purely descriptive criteria an assumption the Pure Theory of Law rejects altogether. ${ }^{197}$

To conclude, it is also possible to recast this rebuttal of Raz in logical terms, namely in the form of a Kantian transcendental argument ${ }^{198}$ through which the sceptic is shown that they cannot help but undermine their own position in the course of defending it. In other words, this specific argument proves that the truth of its conclusion is a necessary condition of there being any cognition of law at all, since if the conclusion were not true, there could be no experience to falsify it. ${ }^{199}$ To this end, Stanley Paulson gives the following example for a transcendental argument to corroborate the need for Kelsen's Grundnorm: 200

1. One has cognition of legal norms (given).

2. Cognition of legal norms is possible only if the category of 'Ought' is presupposed (via the basic norm) (transcendental premise).

Ergo: The category of 'ought' (on the basis of the basic norm) is presupposed (transcendental conclusion).

To put it succinctly, Raz acknowledges that what Hart's complex social practice theory (on the basis of the rule of recognition) fails to accomplish, namely to endow the legal norms of a given system with binding force, can be achieved in Kelsen's theory by the conferral of

\footnotetext{
195 Vinx, Hans Kelsen's Pure Theory of Law (n 10) 192-193.

196 Valentin Petev, 'Rechtsquellenlehre und Reine Rechtslehre' [1984] Rechtstheorie (Beiheft 5) $273,285$.

${ }^{197}$ Vinx, Hans Kelsen's Pure Theory of Law (n 10) 193.

${ }^{198}$ Cf. Immanuel Kant, Prolegomena to Any Future Metaphysics (1783) § 5 and $\S 18-22$; Kant, Critique of Pure Reason (n 33) A 95-130 / B 130-169.

${ }^{199}$ Barry Stroud, 'Transcendental Arguments' (1968) 65 The Journal of Philosophy 241, 252; Quasim Cassam, 'Self-Directed Transcendental Arguments' in Robert Stern (ed), Transcendental Arguments: Problems and Prospects (Oxford: Oxford University Press, 1999) 86.

${ }^{200}$ Stanley L. Paulson, 'On Transcendental Arguments, Their Recasting in Terms of Belief, and the Ensuing Transformation of Kelsen's Pure Theory of Law’ (2000) 75 Notre Dame Law Review 1775, 1790-1791 and 1793.
} 
'Ought' through the basic norm. Due to the purity of the Pure Theory of Law, the Grundnorm is the only norm that is capable of conferring validity on the positive law, and nothing else. ${ }^{201}$ Thus Raz's negative view of the basic norm in general does not stand in the way of a sustained analysis of Kelsen's theory, and particularly of the question: 'In what sense is the basic norm presupposed? ${ }^{202}$

In sum, Raz's critique must therefore be rejected.

\section{CONCLUSION}

After this extensive analysis, the present conclusion can certainly give only a very brief overall appraisal of the Pure Theory of Law, as developed by the Vienna School of Jurisprudence. To begin with, one should not underestimate the philosophical foundations of this theory in the spirit of Immanuel Kant and his successors, that is, a transcendental philosophy and epistemology in the sense that cognition is not concerned with the actual objects of cognition, but the manner how we cognize objects, and, more importantly, in so far as this manner of cognition is possible a priori'. ${ }^{203}$ Equally, one should not forget, however, that Kelsen considers the Pure Theory of Law to be a theory of positive law in general, ${ }^{204}$ not an a priori theory. This means that it builds upon the empirically extant legal material and that it develops therefrom, in an abstracting fashion, a description of the characteristics that all legal structures share throughout space and time. ${ }^{205}$ Yet what is of an a priori and thereby non-contingent nature is the notion of the Grundnorm which, as a logico-transcendental presupposition for cognizing legal reality, is comparable to the Kantian categories, ${ }^{206}$ making possible the constituting of experience in the first place. Like these categories, the Grundnorm shapes the sensory material, thereby condensing it into the unity of the object of cognition and making it

\footnotetext{
${ }^{201}$ Raz, 'The Purity of the Pure Theory' (n 190) 458-459.

202 Bindreiter, Why Grundnorm? (n 113) 91-92.

${ }^{203}$ Kant, Critique of Pure Reason (n 33) B 26.

${ }^{204}$ Kelsen, Pure Theory of Law (n 26) 1.

${ }^{205}$ Ulrich Klug, 'Hans Kelsens Reine Rechtslehre' in in Die Reine Rechtslehre in wissenschaftlicher Diskussion [no editor] (Vienna: Manz, 1982) 31; Hammer (n 65) 215 et seq.; Robert Alexy, 'Hans Kelsens Begriff des relativen Apriori' in Robert Alexy, Lukas H. Meyer, Stanley L. Paulson, and Gerhard Sprenger (eds), Neukantianismus und Rechtsphilosophie (Baden-Baden: Nomos, 2002) 194.

${ }^{206}$ Cf. Kant, Critique of Pure Reason (n 33) A 77 / B 102 - A 80 / B 106. Cf. also Otfried Höffe, Kants Kritik der Reinen Vernunft: Die Grundlegung der modernen Philosophie (Munich: C.H. Beck, 2003) 129-131; Heinz Heimsoeth, 'Zur Herkunft und Entwicklung von Kants Kategorientafel' (1963) 54 Kant-Studien 376 et seq.; Mario Caimi, 'Einige Bemerkungen über die Metaphysische Deduktion in der Kritik der Reinen Vernunft' (2000) 91 Kant-Studien 257 et seq.
} 
accessible to the observing and experiencing subject. By providing for the 'Ought' of legal norms and hence their validity, the basic norm allows the jurist to interpret acts of will as legal acts, whilst the basic norm in itself must be presupposed. ${ }^{207}$ The reason for this is and remains Hume's law, i.e. that legal norms, as normative entities, can logically only be derived from other norms, not from facts. ${ }^{208}$

Consequently, by strictly distinguishing between the 'Is' of the empirical and the 'Ought' of the normative world, the Pure Theory of Law accomplishes three goals: first, the stringent and consistent differentiation from extra-juridical elements, that is, metaphysics in the shape of morality, and brute facts in the form of sociology, politics, and psychology ${ }^{209}-\mathrm{a}$ feat for which Hart even lauded Kelsen. ${ }^{210}$ Second, it thereby aims at the 'scientification' of the law through a descriptive methodology, thus describing what the law is, and not what it should $b^{211}$ (despite the rather complex dual nature of law as a human-made and hence posited fact and a behaviour-regulating normative entity). Lastly, the Pure Theory of Law is accordingly able to describe the law as a dynamic and self-creating system on the basis of Merkl's hierarchy of norms, culminating in the Grundnorm in order to avoid an infinite regress, according to which one can ascertain whether a certain legal norm is a member of a given legal order or not, entailing that non-members are to be presumed invalid. In a logically clear manner, it explains how it is possible to cognize both the creation and the change of the law on the basis of the chains of delegation and derogation in conformity with the duality of 'Is' and 'Ought'.

The last substantial merit to be mentioned and repeated here is the Pure Theory's potential to be extrapolated beyond the boundaries of national law. ${ }^{212}$ If we assume that a legal

\footnotetext{
${ }^{207}$ Norbert Leser, 'Die Reine Rechtslehre im Widerstreit der philosophischen Ideen' in Die Reine Rechtslehre in wissenschaftlicher Diskussion [no editor] (Vienna: Manz, 1982) 100-102; Gerhard Luf, 'On the Transcendental Import of Kelsen's Basic Norm' in Stanley L. Paulson and Bonnie Litschewski-Paulson (eds), Normativity and Norms: Critical Perspectives on Kelsenian Themes (Oxford: Oxford University Press, 2007) 222.

${ }^{208}$ Cf. generally Gerhard Schurz, The Is-Ought Problem: An Investigation in Philosophical Logic (Dordrecht: Kluwer, 1997). For a critical discussion cf. e.g., Max Black, "The Gap between "Is" and "Should"' (1964) 73 The Philosophical Review 165-181; Norbert Achterberg, 'Brücken zwischen Sein und Sollen: Autonome Determinante und modal indifferentes Substrat' [1984] Rechtstheorie (Beiheft 5) 445-452.

${ }^{209}$ Peter Koller, 'Meilensteine des Rechtspositivismus im 20. Jahrhundert: Hans Kelsens Reine Rechtslehre und H.L.A. Harts "Concept of Law" in Ota Weinberger and Werner Krawietz (eds), Reine Rechtslehre im Spiegel ihrer Fortsetzer und Kritiker (Vienna/New York: Springer, 1988) 131-133; Otto Pfersmann, 'Hans Kelsens Rolle in der gegenwärtigen Rechtswissenschaft' in Robert Walter, Werner Ogris, and Thomas Olechowski (eds), Hans Kelsen: Leben - Werk - Wirksamkeit (Vienna: Manz, 2009) 370.

${ }^{210}$ Hart, 'Answers to Eight Questions' (n 20) 289.

${ }^{211}$ Pierluigi Chiassoni, 'Wiener Realism' in Luís Duarte d'Almeida, John Gardner, and Leslie Green (eds), Kelsen Revisited: New Essays on the Pure Theory of Law (Oxford: Hart Publishing, 2013) 152-153.

${ }^{212}$ Cf. Stefan Griller, 'Der Stufenbau der österreichischen Rechtsordnung nach dem EU-Beitritt' (2000) 8 Journal für Rechtspolitik 273, 283 fn 69; Heinz Peter Rill, 'Grundlegende Fragen bei der Entwicklung eines Rechtsbegriffs' in Stefan Griller and Heinz Peter Rill (eds), Rechtstheorie: Rechtsbegriff - Dynamik - Auslegung (Vienna/New York: Springer, 2011) 10 and 12; Starke, 'The Primacy of International Law' (n 96) 308-310.
} 
norm can only be valid if it has been created in full compliance with superior norms within the Stufenbau, and also accept international law as proper law, then it necessarily follows that all law, both national and international law, form part of one unitary legal order. ${ }^{213}$ Furthermore, it is also evident that legal monism, as an epistemological and logical necessity and in contrast to Kelsen's 'choice hypothesis', is only conceivable under the primacy of the international legal order, i.e. with a common Grundnorm at the apex of law in its entirety and international law sitting at the top of the chain of delegation. Otherwise, if we assume the national legal orders to give validity to international norms, the notion of international law would be reduced to a mere absurdity, as there would be as many international legal orders as there are States and other international legal subjects. Thus, international law necessarily delegates national law logically, not historically, through the principle of effectiveness, both enabling States to be effective legal orders and constraining them in their powers on the international plane. Hence, in such a monist legal order, there can be no difference in source, substance, and subjects of these two bodies of law, which also entails that normative conflicts between national and international law are not principally irresolvable, as dualism and pluralism claim.

At the end of the day, and despite considerable criticism by other eminent legal scholars such as Hart and Raz, the Pure Theory of Law and its logical offspring legal monism therefore have the unquestionable merit of being able to examine the structure of the law in a way that enables jurists to comprehend the legal material and to eventually put it into practice. ${ }^{214}$ Critics might argue that legal theory does not yield any immediate benefits, but it is nonetheless all the more able to contribute indirectly to the understanding of the law. And in this vein, particularly the Pure Theory of Law has been described as being able to foster analytical thinking and problem-solving and to thereby support lawyers in solving concrete legal problems on the basis of a certain underlying logical standard. ${ }^{215}$

\footnotetext{
213 Somek, 'Kelsen Lives' (n 28) 451.

${ }^{214}$ Michael Thaler, 'Rechtsphilosophie und das Verhältnis zwischen Gemeinschaftsrecht und nationalem Recht' (2000) 8 Journal für Rechtspolitik 75, 76; Heinz Mayer, 'Rechtstheorie und Rechtspraxis' in Clemens Jabloner and Friedrich Stadler (eds), Logischer Empirismus und Reine Rechtslehre: Beziehungen zwischen dem Wiener Kreis und der Hans Kelsen-Schule (Vienna: Springer, 2001) 319.

${ }^{215}$ Rill, 'Internationales, supranationales und nationales Recht - eine Einheit' (n 77) 700.
} 